\title{
A Mass-Balance Nitrate Model for Predicting the Effects of Land Use on Ground-Water Quality
}

By Michael H. Frimpter, U.S. Geological Survey; John J. Donohue, IV, Massachusetts Department of Environmental Quality Engineering, Division of Water Supply; and Michael V. Rapacz, Massachusetts Department of Environmental Quality Engineering, Division of Water Pollution Control

U.S. GEOLOGICAL SURVEY

Open-File Report 88-493

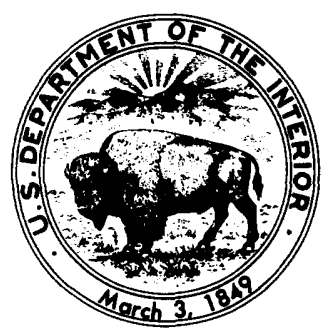

Prepared in cooperation with

MASSACHUSETTS DEPARTMENT OF ENVIRONMENTAL QUALITY ENGINEERING CAPE COD PLANNING AND ECONOMIC DEVELOPMENT COMMISSION U.S. ENVIRONMENTAL PROTECTION AGENCY, REGION I

Boston, Massachusetts 1990 


\section{DEPARTMENT OF THE INTERIOR \\ MANUEL LUJAN, JR., Secretary \\ U.S. GEOLOGICAL SURVEY \\ Dallas L. Peck, Director}

For additional information, write to:

\section{District Chief}

U.S. Geological Survey

Water Resources Division

10 Causeway Street, Suite 926

Boston, MA 02222-1040
Copies of this report can be purchased from:

Books and Open-File Reports Section

U.S. Geological Survey

Box 25425, Federal Center

Denver, CO 80225 


\section{CONTENTS}

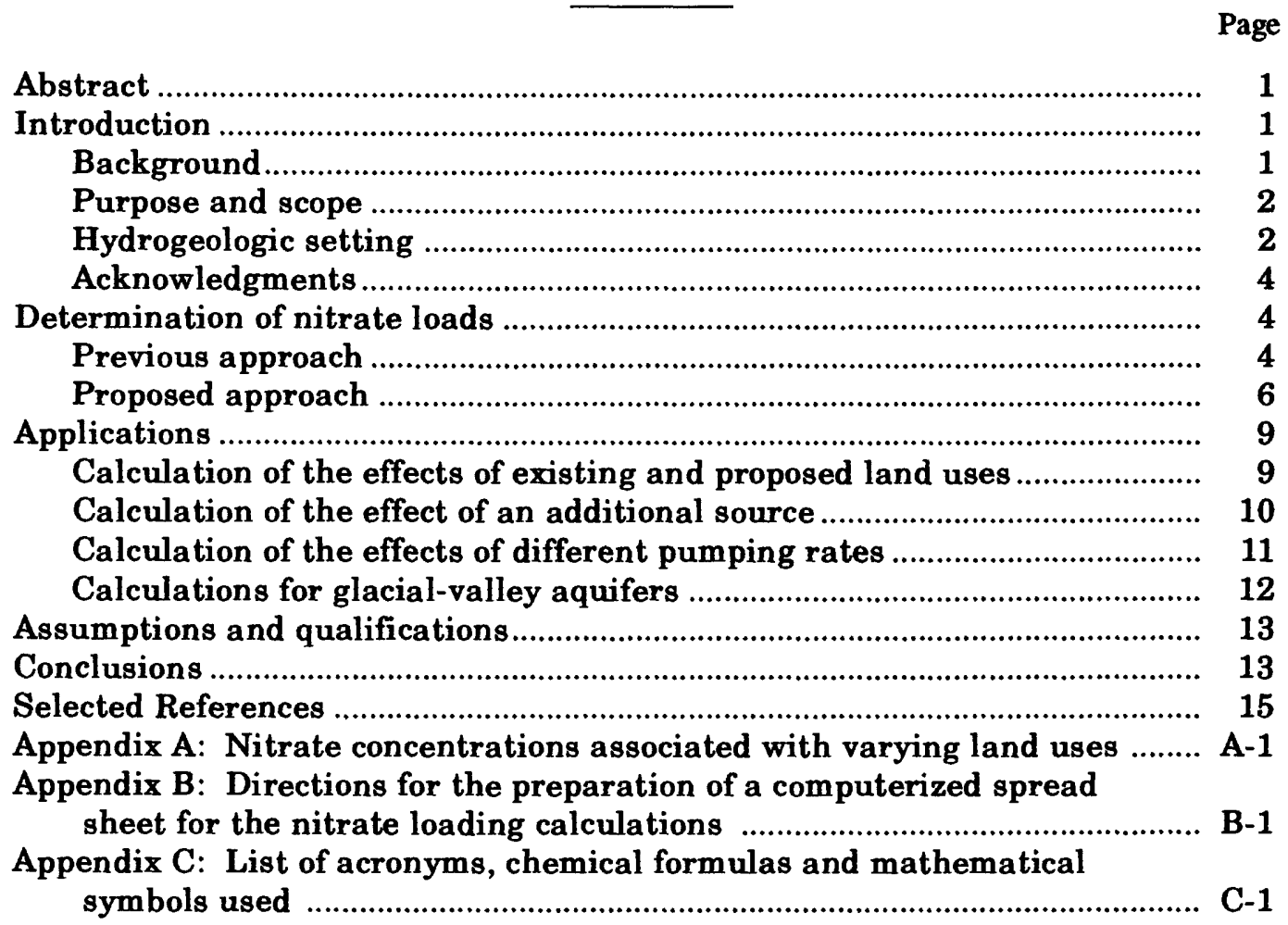

\section{ILLUSTRATIONS}

Figure 1. Hydrologic section of recharge areas to a pumped well in a valley-fill aquifer..... 3

2. Block diagram of house lot showing inflow of nitrate diluted with recharge from precipitation

3. Block diagram of municipal wellhead protection area (Zone II) to a public-supply well showing the zone that contributes water to the well........ 6

4. Sources of nitrate and zones of contribution to a public-supply well pumped at 1 million gallons and 0.5 million gallons per day

5. Map view of glacial-valley aquifer showing the recharge zones and stream which contribute water to a public-supply well

\section{TABLES}

Table 1. Summary of nitrate loads from septic systems for an average one day period for al million gallon per day well ........................................... 9

2. Summary of solid nitrate loads

3. Increase in nitrate load due to proposed hospital development for a 1 million gallon per day public-supply well

4. Summary of nitrate loads from septic systems for an average one day period for a0.5 million gallon per day public-supply well

5. Summary of solid nitrate loads for an average one day period for a 0.5 million gallon per day well 


\section{CONVERSION FACTORS AND ABBREVIATIONS}

For the convenience of readers who may prefer to use metric (International System) units rather than the inch-pound units used in this report, values may be converted by using the following factors.

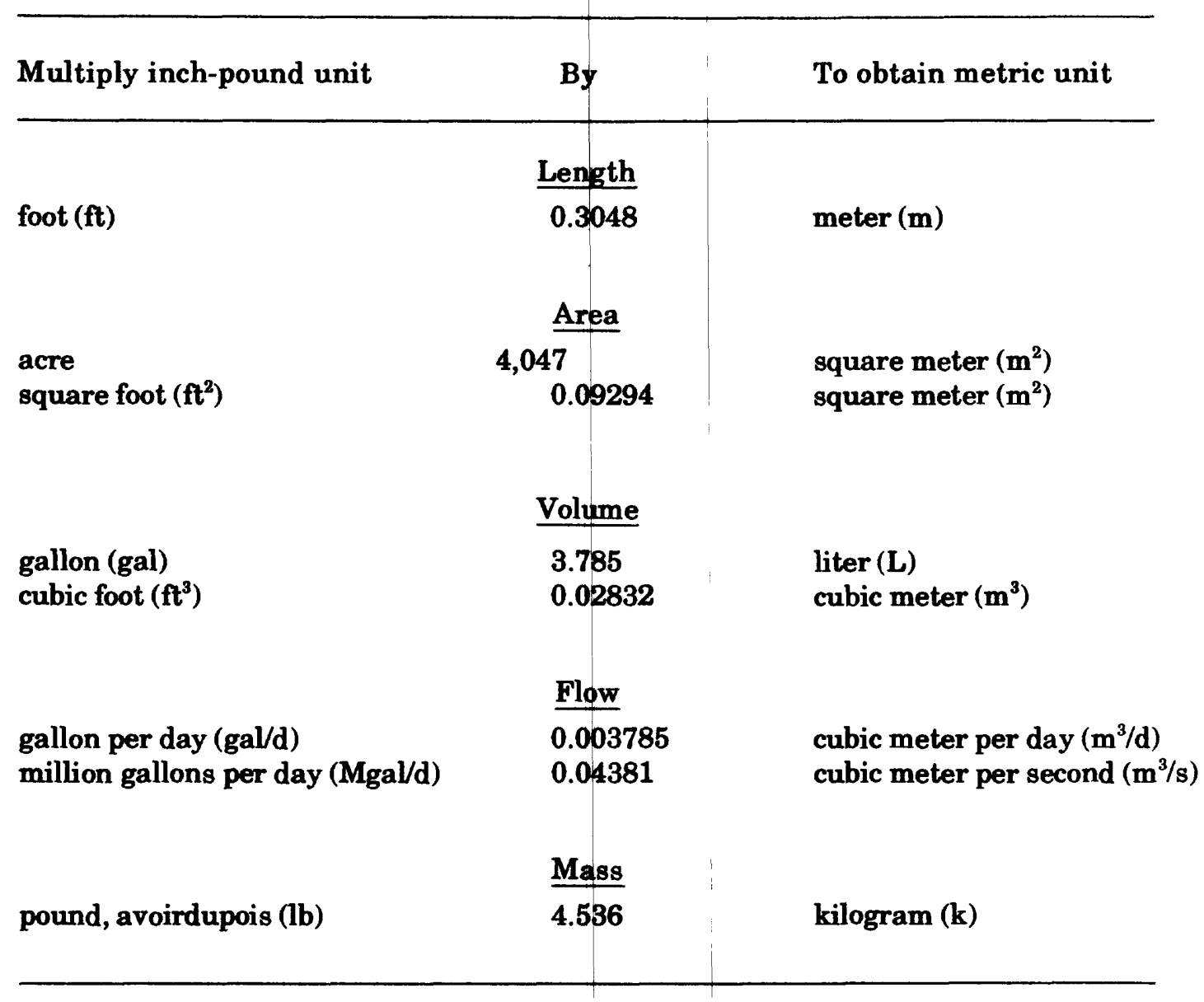




\section{A Mass-Balance Nitrate Model forPredicting the Effects of Land Use on Ground-Water Quality}

By Michael H. Frimpter, U.S. Geological Survey; John J. Donohue, IV, Massachusetts Department of Environmental Quality Engineering, Division of Water Supply; and Michael V. Rapacz, Massachusetts Department of Environmental Quality Engineering, Division of Water Pollution Control

\section{ABSTRACT}

A mass-balance accounting model can be used to guide the management of septic systems and fertilizers to control the degradation of ground-water quality in zones of an aquifer that contribute water to public-supply wells. The nitrate concentration of the mixture in the well can be predicted for steady-state conditions by calculating the concentration that results from the total weight of nitrogen and total volume of water entering the zone of contribution to the well. These calculations will allow waterquality managers to predict the nitrate concentrations that would be produced by different types and levels of development, and to plan development accordingly. Computations for different development schemes provide a technical basis for planners and managers to compare water-quality effects and to select alternatives that limit nitrate concentration in wells. Tables of nitrate loads and water volumes from common sources for use with the accounting model are given.

\section{INTRODUCTION}

\section{Background}

Protection of ground-water quality for public water supply use has become a priority environmental issue. In recent years, one ubiquitous cause of degradation of ground-water quality has been nitrate contributed by subsurface wastewater disposal systems and agricultural activities. In New England, where shallow, unconsolidated aquifer systems provide large quantities of public drinking water and also receive large quantities of waste-water, the potential for water-quality degradation is a primary concern. In order for these two potentially conflicting activities to coexist within acceptable limits, the interrelation between withdrawal for water supply and wastewater discharge needs to be accurately defined. This definition requires a characterization of the aquifer system and quantification of the contribution of nitrate to ground water from land use. 


\section{Purpose and scope}

The purpose of this paper is to provide an approach for evaluating the cumulative effects of nitrogen contributing land uses on water quality in public-supply wells. The method used computes the sum of all nitrate sources within the recharge area of a public-supply well in order to predict steady-state nitrate concentrations in the well water.

Specifically, the paper presents a massbalance accounting equation, tables of nitrate as nitrogen concentrations and flow volumes (Appendix A), and general model examples and directions for the preparation of a computerized spreadsheet for the mass-balance accounting model (Appendix B) for application to those areas that recharge the zones that contribute water to a well. The model may be appropriately applied to wellhead protection areas when those areas are derived from delineation of the areas that contribute recharge to a well, as they are in Massachusetts.

The proposed approach departs from previous nitrate loading approaches used in Massachusetts, by comprehensively accounting for nitrate inputs to that part of an aquifer that contributes water to a well. Properly applied, this approach will provide the necessary scientific foundation for planning development through land-use management, to keep nitrate concentrations at the wellhead below a chosen threshold value. Anyone intending to apply this approach needs to examine the Assumptions and Qualifications section of this paper.

Nitrate was chosen as the ground-water contaminant of concern for several reasons: Dilution is the principal mechanism by which nitrate in ground water is attenuated. Nitrate functions as a conservative chemical species after entering the saturated zone; it is not sorbed by aquifer materials nor is it removed by chemical reactions. Although nitrogen may be introduced to ground water in several dissolved forms, the proposed approach assumes that all nitrogen in ground water is converted to nitrate before reaching a public-supply well. Secondly, two health hazards are related to the consumption of water containing large concentrations of nitrate (or nitrite): induction of methemoglobinemia, particularly in infants, and potential formation of carcinogenic nitrosamines (National Research Council, 1977). Because of these health related concerns, the U.S. Environmental Protection Agency (1975) has established a maximum contaminant level for nitrate as nitrogen in drinking water at $10 \mathrm{mg} / \mathrm{L}$ (milligrams per liter). Nitrate, as used hereafter in this report, refers to nitrate as nitrogen. In addition, the results of a study in Australia imply that the consumption of drinking water containing elevated concentrations of nitrate during pregnancy is associated with a significantly increased risk of malformations in offspring (Dorsch, 1984). Although nitrate may not be the cause of malformations, it is associated with their presence. It has been demonstrated that nitrate is a geochemical indicator for other more toxic contaminants associated with wastewater (Dorsch, 1984, Dewalle and others, 1985 and LeBlanc, 1984).

\section{Hydrogeologic Setting}

Glacial outwash and ice-contact deposits of sand and gravel form the most productive aquifers in Massachusetts and New England. These water-table aquifers are most commonly less than $25 \mathrm{ft}$ (feet) below land surface and less than $100 \mathrm{ft}$ thick. They are typically located either on broad plains or in low valley areas adjacent to the streams of the region. Because these aquifers are recharged from the land immediately overlying them, ground-water quality is highly dependent on local land uses. Massachusetts has developed an approach to managing ground-water quality that focuses management efforts on the land that recharges the parts of aquifers that contribute water to wells.

The delineation of the land area that provides recharge to a pumped well is a prerequisite for applying the methodology set forth in this paper. In Massachusetts, the land surface that contributes recharge to a public-supply well is referred to as Zones II and III by the Department of Environmental Quality Engineering. Zones I, II, and III are defined in 310 CMR 24.00 (Massachusetts Department of Environmental Quality Engineering, 1983) and shown in figure 1.

Zone $I$ is the protective radius around a public water-supply well or wellfield owned or controlled by the water supplier, as required by the Massachusetts Division of Water Supply. 

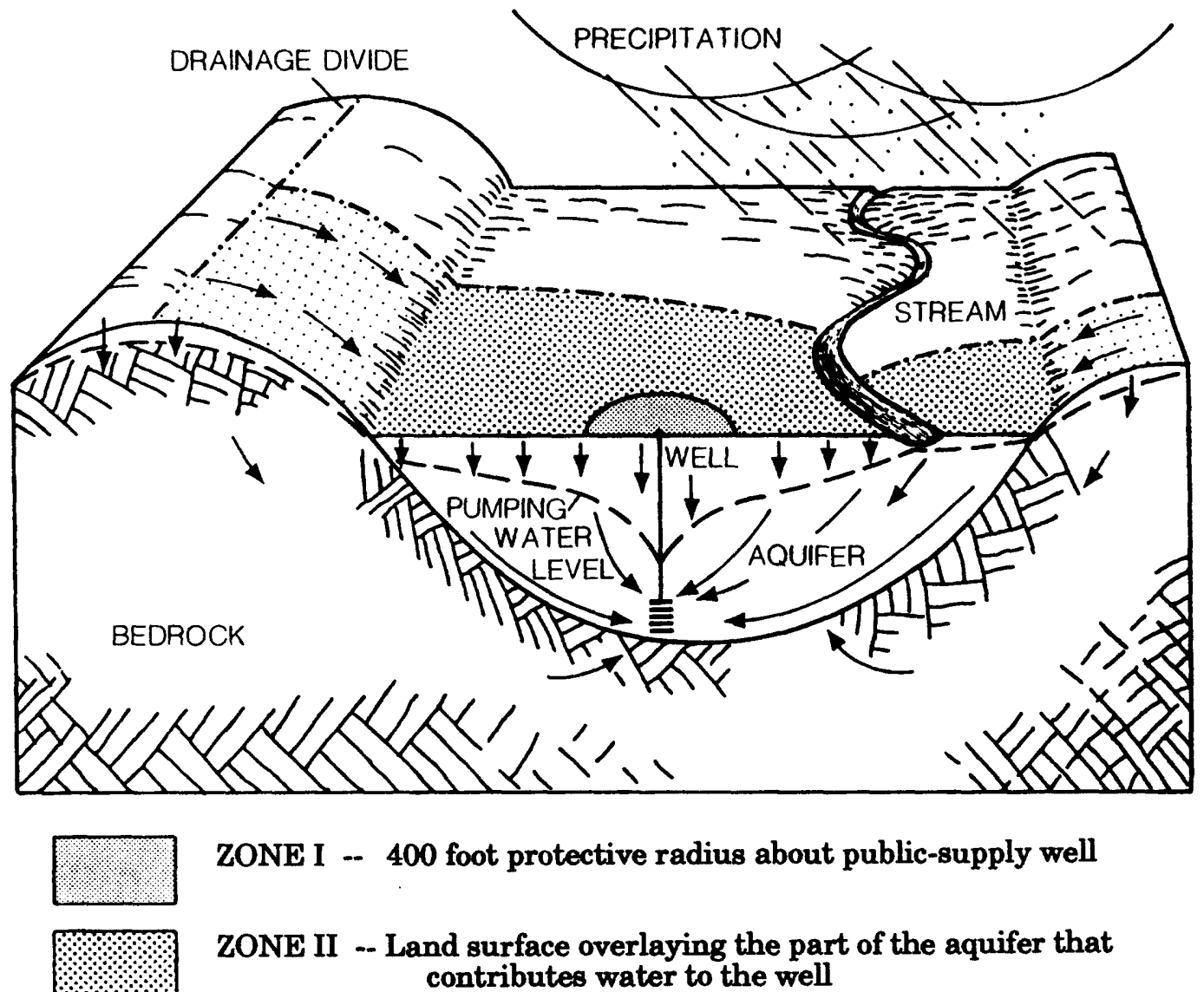

ZONE I -- 400 foot protective radius about public-supply well

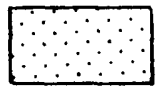

ZONE II -- Land surface overlaying the part of the aquifer that
contributes water to the well

ZONE III -- Land surface through and over which water drains into Zone II

-..-.- DRAINAGE DIVIDE

$\longleftarrow$ DIRECTION OF WATER FLOW

Figure 1.--Recharge areas to a pumped well in a valley-fill aquifer.

Zone II (the Municipal Wellhead Protection Area) is defined in $310 \mathrm{CMR} 24.00$ as "The area of an aquifer that recharges a well (the land surface which overlays that part of the aquifer that recharges a well) under the most severe recharge and pumping conditions that can be realistically anticipated. It is bounded by the ground-water divides that result from pumping the well and by the contact of the edge of the aquifer with less permeable materials such as till and bedrock."

Zone III is defined as "That land area beyond the area of Zone II from which surface water and ground water drain into Zone II. The surface drainage area as determined by topog- raphy is commonly coincident with the groundwater drainage area (ground-water divides in the upland materials) and will be utilized to delineate Zone III. In some locations, where surface-water and ground-water drainage are not coincident, Zone III shall consist of both the surface drainage area and the ground-water drainage area."

Zone II and Zone III are two-dimensional map projections of a three-dimensional subsurface volume. As such, the proper delineation of Zone II and Zone III need to account for significant aspects of the surface-water and ground-water hydrogeology -- when a well is pumped, the resulting Zone II and associated 
Zone III represent a state of physical equilibrium. This state of physical equilibrium is reached (after days, weeks, or months), and maintained when the withdrawal from the aquifer because of pumping is balanced by various recharge mechanisms. These mechanisms include: areal recharge from precipitation; recharge from induced infiltration of surface water; recharge from subsurface wastewater disposal systems; and recharge from overland runoff and ground water that drain from Zone III into Zone II. An accurate delineation of Zone II and Zone III would account for these various recharge mechanisms in their relative proportions. For a more detailed treatment of the determination of Zone II and Zone III see Massachusetts Department of Environmental Quality Engineering (1986) and Donohue (1986).

Within Zone II, all ground water flows toward and converges at the well. This results in a complete mixing effect of the water (and associated contaminants) at the well as it is withdrawn from the aquifer.

The mass-balance accounting model presented in this paper is used to predict nitrate concentrations at the municipal wellhead. The concentrations predicted represent steady-state conditions at the wellhead.

In the field, steady-state conditions are reached when physical and dilution equilibrium are attained. Physical equilibrium is attained when the volume of water contributed by the various recharge mechanisms matches the amount of water withdrawn. Dilution equilibrium is attained at the wellhead when the concentration of nitrate in the various recharge mechanisms stabilizes, and that recharge (water and associated nitrate) has had sufficient time to move from the most distant regions of the Zone $I 1$ to the wellhead. Steady-state conditions may take tens of years or more to achieve, after nitrate loads to the Zone II have stabilized. The amount of time necessary to achieve steadystate depends on the rate of movement of ground water in the Zone II being considered.

In summary, the delineations of Zone II and Zone III are important because water of impaired quality recharging the ground-water system within these areas ultimately will affect the quality of water at the wellhead. When steadystate conditions have been reached, the water quality observed at the wellhead represents the sum of the constituents (ratio of nitrate to the volume of water pumped) entering the Zone II. Accordingly, the management of nitrate loading within the Zone II and Zone III areas is an effective approach to prevent contamination of municipal-supply wells by nitrate.

\section{Acknowledgments}

The authors express their appreciation to the Cape Cod Aquifer Management Project (CCAMP) for providing the impetus and forum to research and develop this document. The CCAMP was initiated in 1985 for the purpose of examining the adequacy of ground-water programs at all levels of government and for developing or recommending modifications of these programs. Members of the project included the Cape Cod Planning and Economic Development Commission (CCPEDC), the Massachusetts Department of Environmental Quality Engineering, the U S. Environmental Protection Agency, Region I, and the U.S. Geological Survey. This report is one of several products of the CCAMP intergovernmental collaboration. The authors also greatly appreciate the assistance of Ms. H. Gile Beye in preparing Appendix B, a user's guide to simplifying data handling.

\section{DETERMINATION OF NITRATE LOADS}

\section{Previous Approach}

Previous work on calculating nitrogen loading to ground water for Massachusetts has focused on the determination of the minimum house lot size (fig. 4) that could be allowed on an aquifer recharge area without violating the nitrate limit ( $10 \mathrm{mg} / \mathrm{L}$ nitrate as nitrogen) for drinking water (Cape Cod Planning and Economic Development Commission, 1978). This approach was based on a mass-balance mixture equation described as follows. The average nitrate load and water volume from a septic system were estimated and the average nitrate load from a lawn was estimated using information available in the literature (see Appendix A). To determine the quantity of recharge required to dilute the nitrate to the limit of $10 \mathrm{mg} / \mathrm{L}$, these estimates of water volume and nitrate load were 


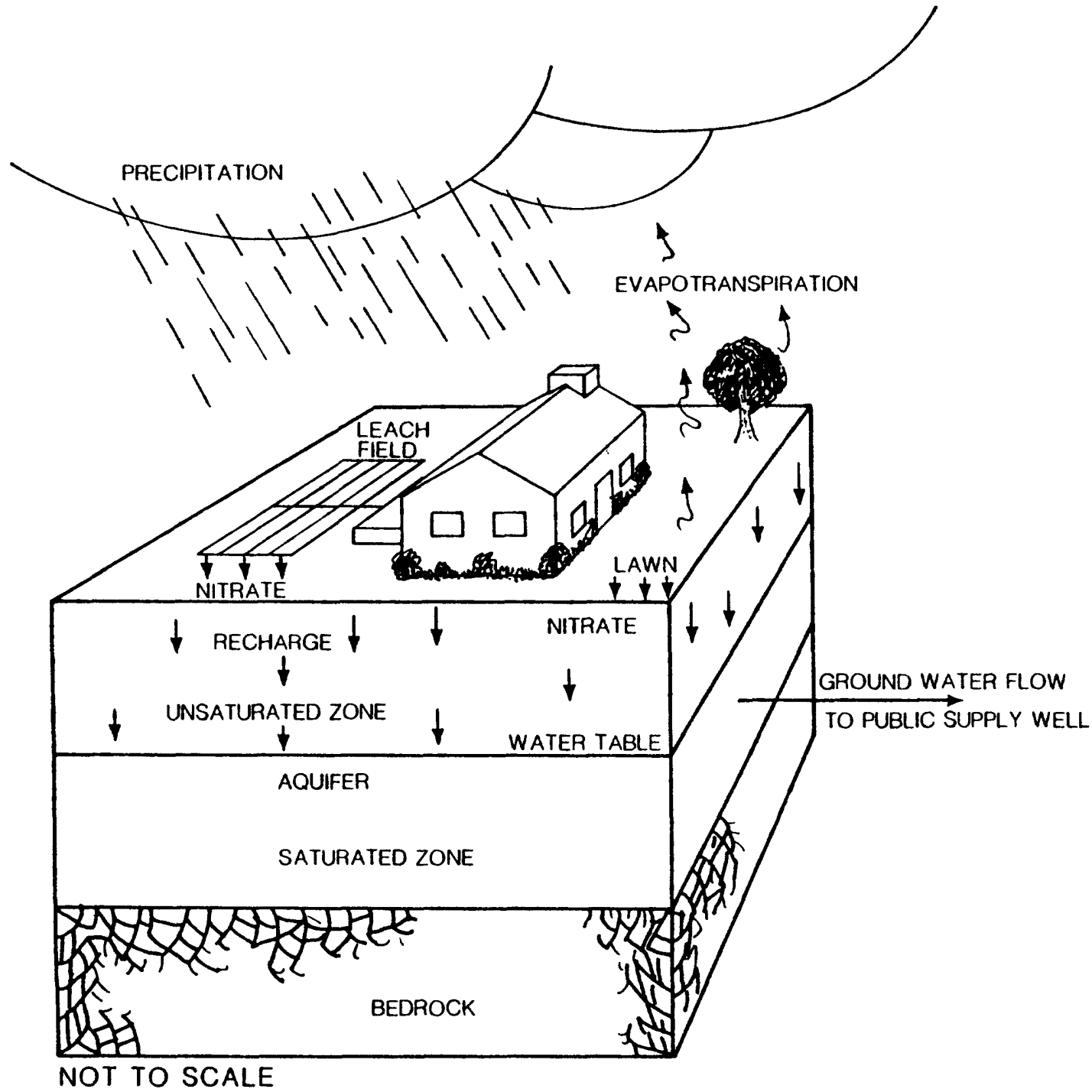

Figure 2.--House lot showing inflow of nitrate diluted with recharge from precipitation.

substituted in a mixture equation similar to the one shown below. All nitrogen from the septic system and fertilizer is assumed to be oxidized to nitrate after traveling through the aquifer to the public-supply well. Although the nitrate limit for drinking water is $10 \mathrm{mg} / \mathrm{L}$, a planning goal of $5 \mathrm{mg} / \mathrm{L}$ was adopted by the CCPEDC to ensure that the health standard would be rarely exceeded (Cape Cod Planning and Economic Development Commission, 1978). The mixture equation could be written as:

Concentration $=\frac{\text { load of nitrate }}{\text { volume of water }}$
Concentration $=\frac{\begin{array}{l}\text { load from } \\ \text { recharge }\end{array}+\begin{array}{c}\text { load from } \\ \text { sources }\end{array}}{\text { total volume of water }}$

where load from recharge equals recharge volume times nitrate concentration in recharge (0.05 $\mathrm{mg} / \mathrm{L}$ nitrate as nitrogen for Cape Cod, Mass.).

The house lot nitrate loads used were 5 pounds per person per year and 9 pounds per year per lawn, or $1,090 \times 10^{4} \mathrm{mg}$ (milligrams) for a 3-person household. The volume of wastewater return flow was 65 gallons per person 
for 3 persons for 365 days, or $7 \times 10^{4}$ gallons ( 27 $\times 10^{4}$ liters) per household per day. Solving the equation for recharge volume (in cubic feet), then dividing by the annual recharge rate (1.33 feet per year), a lot size of $59,250 \mathrm{ft}^{2}$ (square feet) (fig. 2) was calculated as being required to capture sufficient recharge to dilute the mixture to the $5 \mathrm{mg} / \mathrm{L}$ nitrate planning goal.

For the Cape Cod 208 Water Quality Management Plan, this value was adjusted to $43,560 \mathrm{ft}^{2}$, or 1 acre, for areas zoned for single family housing "after allowing for standard percentages of roads and open space associated with residential development" (Cape Cod Planning and Economic Development Commission, 1979). Land-use data for housing and open space supporting this adjustment were not provided (Cape Cod Planning and Economic Development Commission, 1979). With use of the nitrate accounting model described in the next section of this report, the need to provide open-space data to justify the adjustment to 1 acre lots is eliminated.

The conclusion that a housing density of one house per acre would meet the planning goal of $5 \mathrm{mg} / \mathrm{L}$ nitrate translated into a general planning guideline to protect ground-water quality. This calculation provided an average limit on housing density; for the protection of groundwater quality, this guideline, or some adaptation of it, has been adopted by many towns and incorporated in their land-use zoning ordinances and development plans.

\section{Proposed Approach}

The intent of this guide and the following equation is to offer a comprehensive approach to limiting nitrate concentrations from all sources

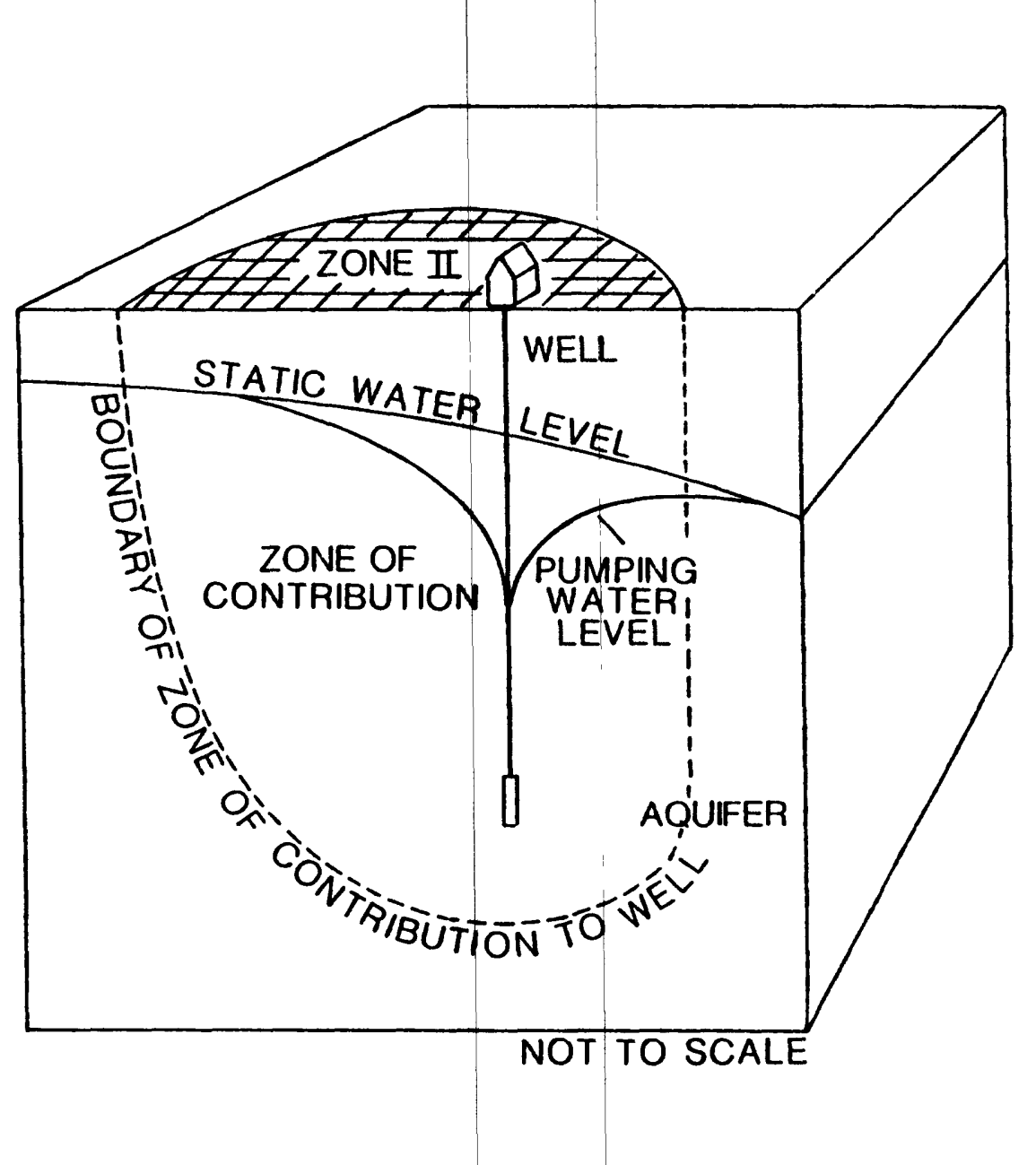

Figure 3.--Municipal wellhead protection area (Zone II ) to a public-supply well showing the zone that contributes water to the well. 
in the zones that contribute water to publicsupply wells (Zone II, as defined by the Massachusetts Department of Environmental Quality Engineering, Division of Water Supply) (fig. 3). Nitrogen from all sources is assumed to be oxidized to nitrate before entering a publicsupply well. The mass-balance accounting model described here is for prediction of steadystate conditions in which all of the nitrate and water entering the Zone II are in equilibrium with and equal to that withdrawn for public supply. Currently observed low concentrations of nitrate are not necessarily indicative of future concentrations because many years may be required to reach steady-state conditions. On the basis of slow movement of ground water, as determined in the Cape Cod aquifer (LeBlanc, 1984), the steady-state condition is estimated to take tens of years or more to be approached in most parts of the Cape Cod aquifer. This method also requires that only a small percentage (less than 25 percent) of the water withdrawn be discharged to and recharged to ground water within Zone II. If a large part of the water produced by a public-supply well were returned to the zone that contributes water to the well (Zone II), then recycled nitrate would dominate the effects of dilution from precipitation and other recharge sources, and nitrate would increase and exceed $10 \mathrm{mg} / \mathrm{L}$. Wells so affected by recycled nitrate will eventually produce water with more than $10 \mathrm{mg} / \mathrm{L}$ nitrate. For these wells, the approach described here is ineffective. For most wells, however, this approach is effective because most public-supply wells supply areas much larger than their Zone II.

Although there are reasons for groundwater quality protection outside of the Zone II, this paper is limited to activities within the wellhead protection area (Zone II) (fig. 4) that affect nitrate concentration in water from the public-supply well. This approach is an expansion of and more complete use of the massbalance dilution equation used previously to determine a maximum average housing density on Cape Cod. An example of the equation and its accounting for all sources follows:

$$
\begin{aligned}
& \text { Nitrate nitrate load + nitrate load } \\
& \text { concentration }=\frac{\text { from precipitation }{ }^{+} \text {from sources }}{\text { total volume of water }}
\end{aligned}
$$

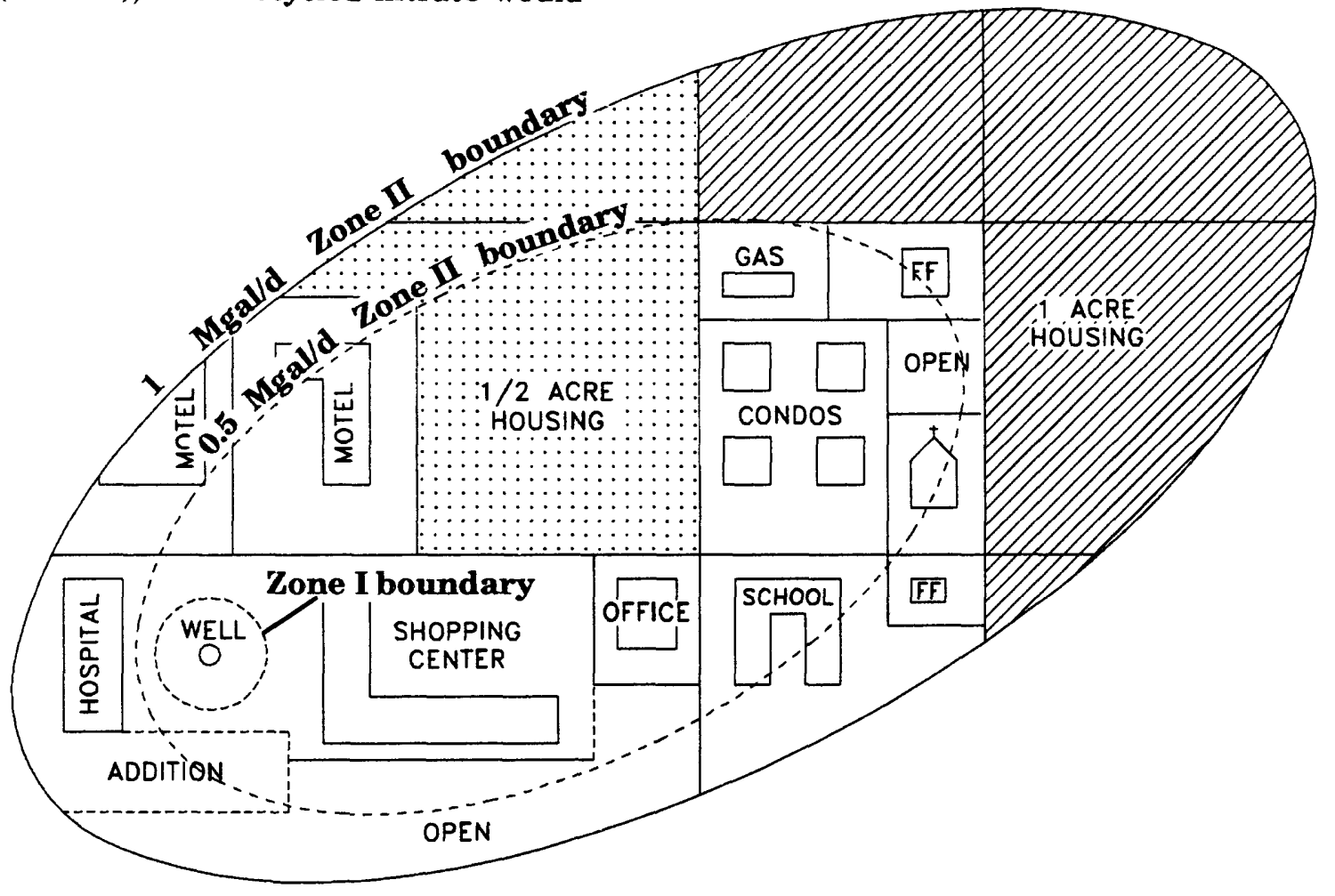

Figure 4.--Sources of nitrate and zones of contribution to a public-supply well pumped at 1 million gallons per day and 0.5 million gallons per day. 


$$
\begin{gathered}
C_{w}=\frac{C_{r}\left(V_{w}-0.9\left(V_{1}+V_{2}+\ldots+V_{n}\right)\right)+}{V_{w}} \\
\frac{\left(L_{1}+L_{2}+\ldots+L_{n}\right)}{V_{w}}
\end{gathered}
$$

where: $\quad C_{w}$ is nitrate concentration of ground water at the well, in milligrams per liter;

$V_{w}$ is volume of withdrawal from well, in liters (volume needs to be converted to liters because concentrations are calculated in milligrams per

\begin{tabular}{|c|c|c|}
\hline $\mathbf{C}_{\mathbf{x}}$ & is & $\begin{array}{l}\text { nitrate concentration in } \\
\text { recharge from precipita- } \\
\text { tion, in milligrams per } \\
\text { liter; }\end{array}$ \\
\hline$L_{1}+L_{2}+\ldots+L_{n}$ & is & $\begin{array}{l}\text { nitrate load, in mil- } \\
\text { ligrams, from individual } \\
\text { sources where } L=C \times V \text {, } \\
\text { when load is calculated } \\
\text { from the volume and } \\
\text { nitrate concentration of } \\
\text { effluent from the source; }\end{array}$ \\
\hline$C_{1}+C_{2}+\ldots+C_{n}$ & is & $\begin{array}{l}\text { nitrate concentration in } \\
\text { individual sources, in } \\
\text { milligrams per liter; and }\end{array}$ \\
\hline$V_{1}+V_{2}+\ldots+V_{n}$ & is & $\begin{array}{l}\text { volume of water used by } \\
\text { each source before dis- } \\
\text { charge to septic system, } \\
\text { in liters. }\end{array}$ \\
\hline
\end{tabular}
liter);

The load of nitrate in recharge from precipitation is the product of nitrate concentration in recharge $\left(C_{r}\right)$ times the volume of recharge derived from precipitation after adjustment for water from other recharge sources $\left(V_{w}-0.9\right.$ $\left.\left(V_{1}+V_{2}+\ldots+V_{n}\right)\right)$. Nitrate concentration in ground-water recharge from precipitation on Cape Cod $\left(C_{r}\right)$ was estimated as $0.05 \mathrm{mg} / \mathrm{L}$ on the basis of an analysis of the frequency distribution of nitrate concentration in ground water. Thirty percent of about 5,000 ground-water samples from Cape Cod had nitrate concentrations of $0.05 \mathrm{mg} / \mathrm{L}$ or less.

The term $L_{1}+L_{2}+\ldots+L_{n}$ is a summation of the loads of nitrate from all sources within the zone. The term $0.9\left(V_{1}+V_{2}+\ldots+V_{n}\right)$ represents the quantity of water returned to the aquifer by the septic systems and other return flows and is subtracted from the withdrawal rate to obtain the quantity of recharge from precipitation that will reach the well. The value of the term $V_{1}+V_{2}+\ldots+V_{n}$ would have been determined for delineation of the zone of contribution (Zone II) and therefore would be available for substitution in the mass-balance nitrate calculation. The sum of the volumes of wastewater are multiplied by 0.9 to adjust for a 10 -percent loss by evapotranspiration as estimated in the previous work by CCPEDC. In other climates where evapotranspiration rates and practices of water users may differ, this adjustment value for water loss may be changed. Nitrogen may be introduced to the ground water in several chemical forms, but is assumed to be oxidized to nitrate before reaching the well. For liquid sources, $C_{1}$ and $V_{1}$ are the concentration of nitrogen, in all its chemical forms, and volume of water contributed by the first source, respectively, $\mathrm{C}_{2}$ and $V_{2}$, the second source, and $C_{n}$ and $V_{n}$, the last (nth) source. These data are compiled, summed and substituted in this equation (3) to calculate an estimate of the nitrate concentration for ground water at the well $\left(C_{w}\right)$. It is recognized that this calculation is an estimate that approximates the concentration of nitrate at a public-supply well under several simplifying conditions, none of which are expected to be fully met in an actual situation. The process of denitrification of ground water has not yet been described in sufficient detail to allow its inclusion in these calculations and is omitted. The resulting influence of this omission on the calculation is expected to be small because of the low rate of the denitrification in ground water, but the calculation should result in a slightly higher estimate than would actually occur. Other inaccuracies of the calculated concentration may be introduced by the imprecision with which the individual loads are estimated, the imprecision of the mapping of the municipal wellhead protection area (Zone II), and the areal variation of recharge from precipitation over the Zone. The nitrate concentrations calculated by this approach are intended to be a guide for broad decisions on limiting land uses that increase nitrate concentrations in water-supply wells. The significance of nitrate as a contaminant and an indicator of contamination for public health in drinking water is described in the introduction to this report. 


\section{APPLICATIONS}

The prediction of nitrate concentration at a well by the dilution accounting approach can be used to evaluate the potential for exceeding nitrate concentration health limits or planning goals. Dilution accounting calculations also can be used to assess the relative effects of various specific land uses or levels of development on water quality. In these applications, nitratedilution accounting is a water-quality planning and management tool that can be used to guide decisions. To calculate nitrate concentrations in milligrams per liter, the water volumes and nitrate weights given in many references and in Appendix A of this report need to be converted to metric units. Some examples of calculations and discussion of their potential use for planning and management of ground-water quality follow.

\section{Calculation of the Effects of Existing and Proposed Land Uses}

A prediction of the effects of land uses, either existing or possible within zoning restrictions, may be calculated by summing the nitrate

Table 1.--Summary of nitrate loads ${ }^{1}$ from septic systems for an average one day period for a 1 million gallon per day well

[gal/d, gallons per day; L/d, liters per day; mg/L, milligrams per liter; mg/d, milligrams per day]

\begin{tabular}{|c|c|c|c|c|c|}
\hline Source & $\begin{array}{l}\text { Flow } \\
(\mathrm{gal} / \mathrm{d})\end{array}$ & $\begin{array}{c}\text { Units } \\
\text { (variable) }\end{array}$ & $\begin{array}{c}\text { Volume } \\
\text { (L/d) }\end{array}$ & $\begin{array}{l}\text { Titrate as nitrog } \\
\text { concentration } \\
(\mathbf{m g} / \mathrm{L})\end{array}$ & $\begin{array}{c}\text { Load } \\
(\mathrm{mg} / \mathrm{d})\end{array}$ \\
\hline 1. $1 / 2$ acre housing & 65/person & 400 people & 98,410 & 40 & $3,936,400$ \\
\hline 2. High school & 20/student & 1,000 student & 75,700 & 40 & $3,028,000$ \\
\hline $\begin{array}{l}\text { 3. Fast food res- } \\
\text { taurant } \\
\text { (counter seat) }\end{array}$ & 150/seat & 70 seats & 39,740 & 40 & $1,589,700$ \\
\hline $\begin{array}{l}\text { 4. Fast food res- } \\
\text { taurant } \\
\text { (table seat) }\end{array}$ & $350 /$ seat & 10 seats & 13,250 & 35 & 463,750 \\
\hline 5. One acre housing & 65/person & 200 people & 49,210 & 40 & $1,968,400$ \\
\hline 6. Condominium & 65/person & 120 people & 29,520 & 40 & $1,180,800$ \\
\hline 7. Shopping center & 60/employee & 50 employees & 11,360 & 40 & 454,400 \\
\hline 8. Office building & 15/employee & 25 employees & 1,420 & 40 & 56,800 \\
\hline 9. Gas station & 500/island & 2 islands & 3,785 & 40 & 151,400 \\
\hline 10. Church & 3/seat & 200 seats & 2,270 & 40 & 90,800 \\
\hline 11. Motel A & 75/person & 40 people & 11,355 & 35 & 397,425 \\
\hline 12. Motel B & 75/person & 160 people & $\mathbf{4 5 , 4 2 0}$ & 35 & $1,589,700$ \\
\hline 13. Hospital & 200/bed & 60 beds & 45,420 & 35 & $1,589,700$ \\
\hline Totals & & $\left(V_{1}+V_{2}+\ldots+V_{13}\right)=$ & 426,860 & \multicolumn{2}{|c|}{$\left(L_{1}+L_{2}+\ldots+L_{13}\right)=16,497,275$} \\
\hline
\end{tabular}

${ }^{1}$ Values are selected from Appendix A, nitrate as nitrogen concentrations in effluent were increased by $5 \mathrm{mg} / \mathrm{L}$ based on the assumption that public water supply would not exceed the $5 \mathrm{mg} / \mathrm{L}$ planning goal, the 453,592 milligram per pound conversion was rounded to 454,000 milligrams per pound, and a conversion factor of 3.785 liters per gallon was used. Volume was rounded to nearest 5 liters. 
Table 2.--Summary of solid nitrate loads

$\left[\mathrm{ft}^{2}\right.$, square feet; lbs/d, pounds per day; mg/d, milligrams per day]

\begin{tabular}{|c|c|c|c|c|}
\hline Source & Units & $\begin{array}{c}\text { Nitrate as nitrogen } \\
\qquad(\mathrm{lbs} / \mathrm{d})\end{array}$ & Milligrams/Pound & $\begin{array}{c}\text { Load } \\
(\mathrm{mg} / \mathrm{d})\end{array}$ \\
\hline 14. Lawns $\left(5,000 \mathrm{ft}^{2}\right)$ & 100 lawns & $0.025^{1}$ & 454,000 & $1,135,000$ \\
\hline $\begin{array}{l}\text { 15. Horses @ } 1,200 \mathrm{lb} \\
\text { each }\end{array}$ & 6 horses & $\begin{array}{r}0.027 / 100 \mathrm{lb} \\
\text { of animal }\end{array}$ & 454,000 & 882,580 \\
\hline Total & & & $\left(L_{14}+L_{15}\right)=$ & $2,017,580$ \\
\hline
\end{tabular}

${ }^{1}$ Based on 9 pounds per year of nitrate leaching into the ground-water system from $5,000 \mathrm{ft}^{2}$ of lawn (Cape Cod Planning and Economic Development Commission, 1979).

loads from recharge from precipitation and from land-use sources and dividing by the volume of water withdrawn (equation 3 and tables 1 and 2),

$$
\begin{aligned}
\left(V_{1}+V_{2}+\ldots+V_{13}\right)= & 426,860 \text { liters } \\
\left(L_{1}+L_{2}+\ldots+L_{15}\right)= & 2,017,580+16,497,275 \\
& =18,514,855
\end{aligned}
$$

By substituting the calculated total volume and total load in the mixture equation described above, the concentration of nitrate at the pumped well can be calculated as follows:

$$
\begin{aligned}
& C_{w}=\frac{C_{r}\left(V_{w}-0.9\left(V_{1}+V_{2}+\ldots+V_{n}\right)\right)+}{V_{w}} \\
& \frac{\left(L_{1}+L_{2}+\ldots+L_{n}\right)}{V_{w}} \\
& C_{w}=\frac{0.05(3,785,000-0.9(426,860))+18,514,855}{3,785,000} \\
& C_{w}=\frac{18,684,896}{3,785,000},
\end{aligned}
$$

where: $\quad V_{w}$ is in liters per day $(1 \mathrm{Mgal} / \mathrm{d}$ $\times 3.785$ );

$$
\begin{gathered}
\mathrm{C}_{\mathrm{r}} \text { is the nitrate concentration } \\
\text { in ground-water recharge } \\
\text { in undeveloped areas of } \\
\text { Cape Cod; } \\
\mathrm{C}_{w} \text { is } 4.94 \mathrm{mg} / \mathrm{L}=\text { nitrate con- } \\
\text { centration at the well. }
\end{gathered}
$$

In this example of a well pumped at 1 million gallons per day, the calculated nitrate con- centration in the well is $4.94 \mathrm{mg} / \mathrm{L}$, close to the planning goal of $5 \mathrm{mg} / \mathrm{L}$. These predictions can be compared with water-quality limits or planning goals to evaluate land-use, zoning, or welllocation decisions.

\section{Calculation of the Effect of an Additional Source}

The advisability of permitting a proposed 40-bed addition to the hospital (table 3, fig. 4) in the zone of contribution can be determined by predicting its effect on nitrate concentration in the well. To calculate the nitrate concentration that would result with the hospital addition, the estimated additional water volume and additional nitrate load can be added to the previously determined totals and the new totals substituted in the equation.

$$
\begin{aligned}
& \left(\mathrm{V}_{1}+\mathrm{V}_{2}+\ldots+\mathrm{V}_{16}\right)=457,140 \text { liters } \\
& \left(\mathrm{L}_{1}+\mathrm{L}_{2}+\ldots+\mathrm{L}_{16}\right)=19,574,655 \text { milligrams } \\
& C_{w}=\frac{C_{r}\left(V_{w}-0.9\left(V_{1}+V_{2}+\ldots+V_{n}\right)\right)+}{V_{w}} \\
& \frac{\left(L_{1}+L_{2}+\ldots+L_{n}\right)}{V_{w}} \\
& C_{w}=\frac{0.05(3,785,000-0.9(457,140))+19,574,655}{3,785,000} \\
& C_{w}=5.22 \mathrm{mg} / \mathrm{L} \text { (nitrate) }
\end{aligned}
$$


Table 3.--Increase in nitrate load due to proposed hospital development for a 1 million gallon per day public-supply well

[gal/d, gallons per day; L/d, liters per day; mg/L, milligrams per liter; mg/d, milligrams per day]

\begin{tabular}{|c|c|c|c|c|c|c|}
\hline \multicolumn{2}{|r|}{ Source } & $\begin{array}{l}\text { Flow } \\
\text { (gal/d) }\end{array}$ & $\begin{array}{c}\text { Units } \\
\text { (variable) }\end{array}$ & \multicolumn{2}{|r|}{$\begin{array}{l}\text { Nitrate as nitrogen } \\
\text { concentration } \\
(\mathbf{m g} / \mathrm{L})\end{array}$} & $\begin{array}{l}\text { Load } \\
(\mathrm{mg} / \mathrm{d})\end{array}$ \\
\hline 16. & $\begin{array}{l}\text { Hospital } \\
\text { addition }\end{array}$ & 200/bed & 40 beds & 30,280 & 35 & $1,059,800$ \\
\hline
\end{tabular}

The calculation includes the water volume and nitrate load that would be caused by the hospital addition. The resultant prediction exceeds the planning goal of $5 \mathrm{mg} / \mathrm{L}$. If the planning goal is to be upheld, then the conclusion could be to deny approval of the hospital addition as proposed. In this way, the nitrate accounting equation becomes a decision-making tool for limiting the amount of nitrate discharged to the wellhead protection area. It can also be used to compare various potential development plans and to select future development alternatives. For example, the effect of sewering could be predicted by subtracting the load of nitrate that would be sewered rather than discharged within the Zone II.

\section{Calculation of the Effects of Different Pumping Rates}

Changes in pumping rates can result in decreased or increased nitrate concentration. This example considers a nonuniform distribution of nitrate sources and a reduced pumping rate. Because a well may not be pumped at the same rate every year and because there is no guarantee that the sources of nitrate will be uniformly distributed within the zone of contribution, additional calculations are advisable. If a lower pumping rate is assumed, then the predicted zone of contribution to the well will be correspondingly smaller and closer to the well. Figure 4 shows the zone of contribution for a well pumped at $1 \mathrm{Mgal} / \mathrm{d}$ (million gallons per day) and a smaller zone of contribution for the same well when pumped at $0.5 \mathrm{Mgal} / \mathrm{d}$. By summing the water volume and nitrate load produced by the sources within the smaller zone and solving the equation to predict the nitrate concentration at the well (tables 4 and 5 ), it is possible to determine whether the $5 \mathrm{mg} / \mathrm{L}$ planning goal would be exceeded at a lower pumping rate. Comparison of the two nitrate concentration predictions under different pumping rates would also indicate whether the sources of nitrate are uniformly distributed within the larger wellhead protection area, or whether they are concentrated close to or far from the well.

$$
\begin{aligned}
& \left(V_{1}+V_{2}+\ldots+V_{7}\right)=241,010 \text { liters } \\
& \left(L_{1}+L_{2}+\ldots+L_{8}\right)=10,071,780 \text { milligrams }
\end{aligned}
$$

$$
\begin{gathered}
C_{w}=\frac{C_{r}\left(V_{w}-0.9\left(V_{1}+V_{2}+\ldots+V_{n}\right)\right)+}{V_{w}} \\
\frac{\left(L_{1}+L_{2}+\ldots+L_{n}\right)}{V_{w}}
\end{gathered}
$$

$C_{w}=\frac{.05(1,892,500-0.9(241,010))+10,071,780}{1,892,500}$

$C_{w}=5.37 \mathrm{mg} / \mathrm{L}$ nitrate

In this example, because the loading sources were more heavily concentrated close to the well, the nitrate concentration predicted for the smaller zone of contribution is higher than that calculated for the larger zone, exceeding the 5 $\mathrm{mg} / \mathrm{L}$ planning goal. Similarly, calculations of load can be expanded to account for larger areas of contribution if additional pumping is planned. 
Table 4.--Summary of nitrate loads from septic systems for an average one day period for a 0.5 million gallon per day public-supply well

[gal/d, gallons per day; L/d, liters per day; mg/L, milligrams per liter; mg/d, milligrams per day]

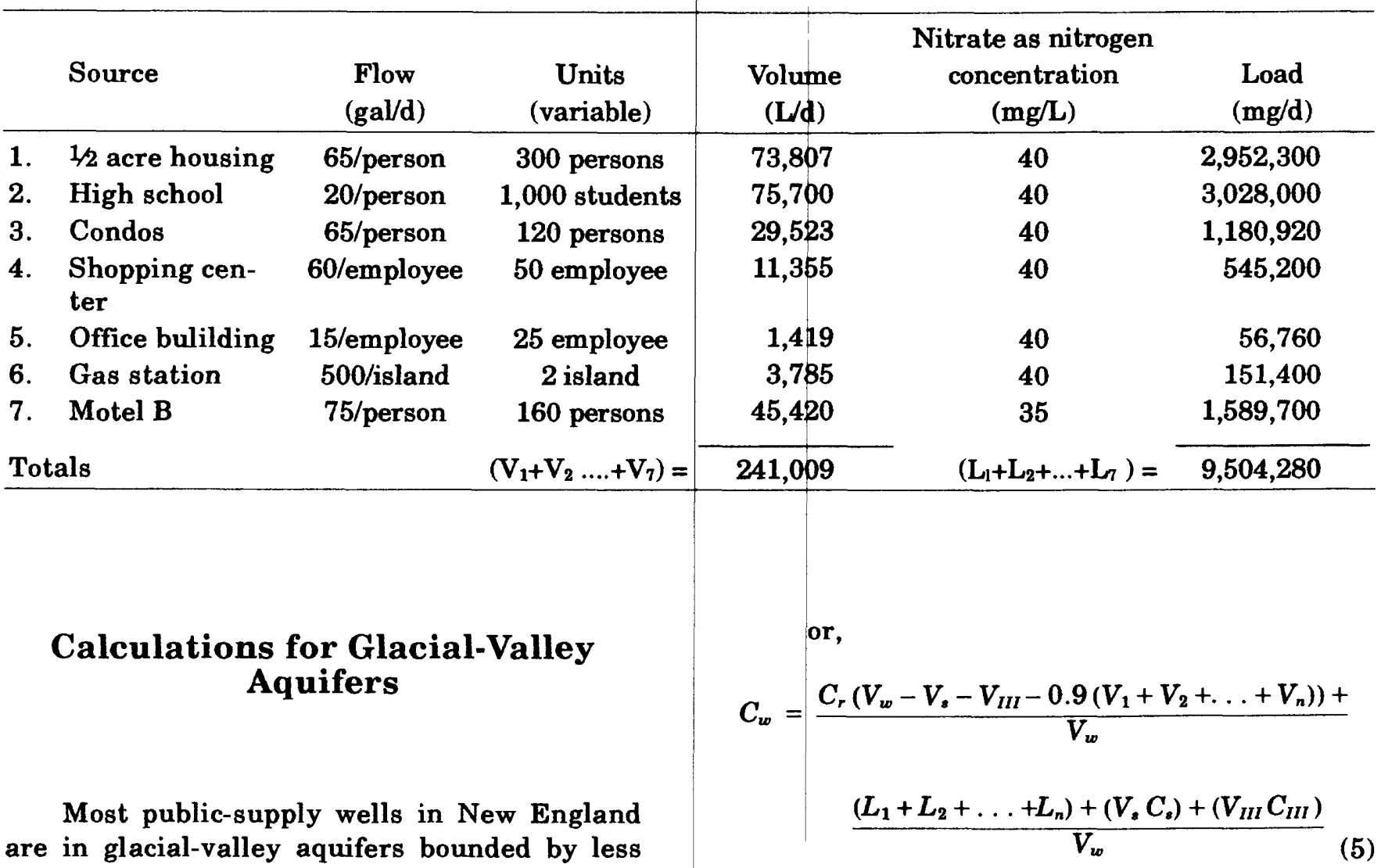
permeable till and bedrock uplands and by streams. To account for nitrate loading in these aquifers, some additional components need to be added to the dilution accounting equation. Where a well derives part of its yield from induced infiltration from a stream (figs. 1 and 5), the quantity of water $\left(V_{s}\right)$ and nitrate concentration $\left(C_{s}\right)$ of the stream water need to be entered into the accounting. Similarly, where water drains from beyond the aquifer into the zone that contributes water to the well (figs. 1 and 5), the volume of that water $\left(V_{\text {III }}\right)$ and the nitrate concentration of that water $\left(\mathrm{C}_{\mathrm{III}}\right)$ need to be entered in the accounting. These considerations result in the following expansion of the dilution accounting equation:

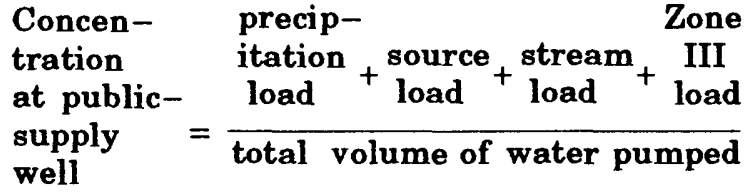

where the new terms are:

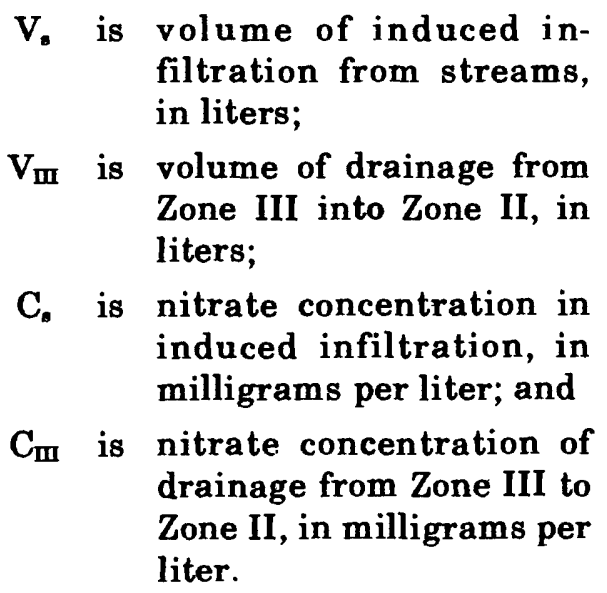

The volume of water from streams and the volume of water from Zone III are essential ingredients for the determination of the zone of contribution to a well (Donohue, 1986 and Morrissey, 1987) and, therefore, need to be available wherever the zone of contribution (Zone II) has been determined. 
Table 5.--Summary of solid nitrate loads for an average one day period for a 0.5 million gallon per day public-supply well

$\left[\mathrm{ft}^{2}\right.$, square feet; lbs/d, pounds per day; mg/d, milligrams per day]

\begin{tabular}{llcccc}
\hline Source & $\begin{array}{c}\text { Units } \\
(\text { variable })\end{array}$ & $\begin{array}{c}\text { Nitrate as nitrogen } \\
(\mathrm{lbs} / \mathrm{d})\end{array}$ & $\begin{array}{c}\text { Milligrams/pound } \\
\text { conversion }\end{array}$ & $\begin{array}{c}\text { Load } \\
(\mathrm{mg} / \mathrm{d})\end{array}$ \\
\hline 8. & $\begin{array}{l}\text { Lawns } \\
\left(5,000 \mathrm{ft}^{2}\right)\end{array}$ & 50 & & & \\
\hline
\end{tabular}

In Massachusetts, nitrate-concentration data for streams may be available from the Division of Water Pollution Control or samples may have to be collected for chemical analysis. Estimates of the nitrate concentration of water draining from Zone III could be made from a dilution accounting calculation for that zone, or chemical analysis of representative water samples might be used.

Appendix B is a computer spreadsheet for applying this accounting approach to a publicsupply well in the most complicated case where there are contributions from surface water and from outside of the aquifer (Zone III). If no water is contributed from these sources, as on Cape Cod, then zeros are entered for $V_{s}, C_{s}, V_{\text {III }}$, and $\mathrm{C}_{\mathrm{III}}$.

From inspection and comparison of the calculated nitrate loads from various sources, a relative ranking of the importance of the sources can be developed. Once the nitrate-loading data are entered into an automatic spreadsheet, such as shown in Appendix B of this report, only minor modifications are necessary to make sensitivity analyses to test for the consequences of different development levels or alternatives. Assessment and comparison of the potential effects of all sources through the nitrate accounting process described here assists in the recognition of the greatest potential sources for contamination of water quality and corresponding selection of priorities and scale of groundwater quality management efforts.

\section{ASSUMPTIONS AND QUALIFICATIONS}

1. The nitrate accounting approach described here provides the necessary information for land-use decisions that may limit groundwater contaminants in the wellhead protection area of wells completed in water-table aquifers. The approach is appropriate for contaminants that are attenuated predominantly by dilution and tolerated in the 1 - to $500-\mathrm{mg} / \mathrm{L}$ range of concentration, such as nitrate, chloride, and total dissolved solids. The approach is not useful for managing or evaluating sources of other types of contamination, such as solvents and fuels. The nitrate predictions that result are approximations of long-term average concentrations, imprecise in that actual concentrations may be expected to be above and below the average. For this reason, a planning standard, or goal, of 5 $\mathrm{mg} / \mathrm{L}$, which is lower than the $10 \mathrm{mg} / \mathrm{L}$ health standard, has been recommended by the CCPEDC and is used in the examples in this guide.

2. The approach assumes that, under steadystate withdrawal conditions, all of the water and nitrate withdrawn from the well are derived from the zone of contribution for the well, and that only some of the water withdrawn is returned to the zone of contribution as return flow. In those situations where a well derives some of its yield from induced infiltration from streams or other surface-water bodies, the quantity and quality of induced infiltration need to be entered in the accounting. The quantity of water derived from induced infiltration would have to be computed in order to delineate the zone of contribution and, therefore, be available for nitrate calculations. In those situations where a well derives some of its yield from an area of till 

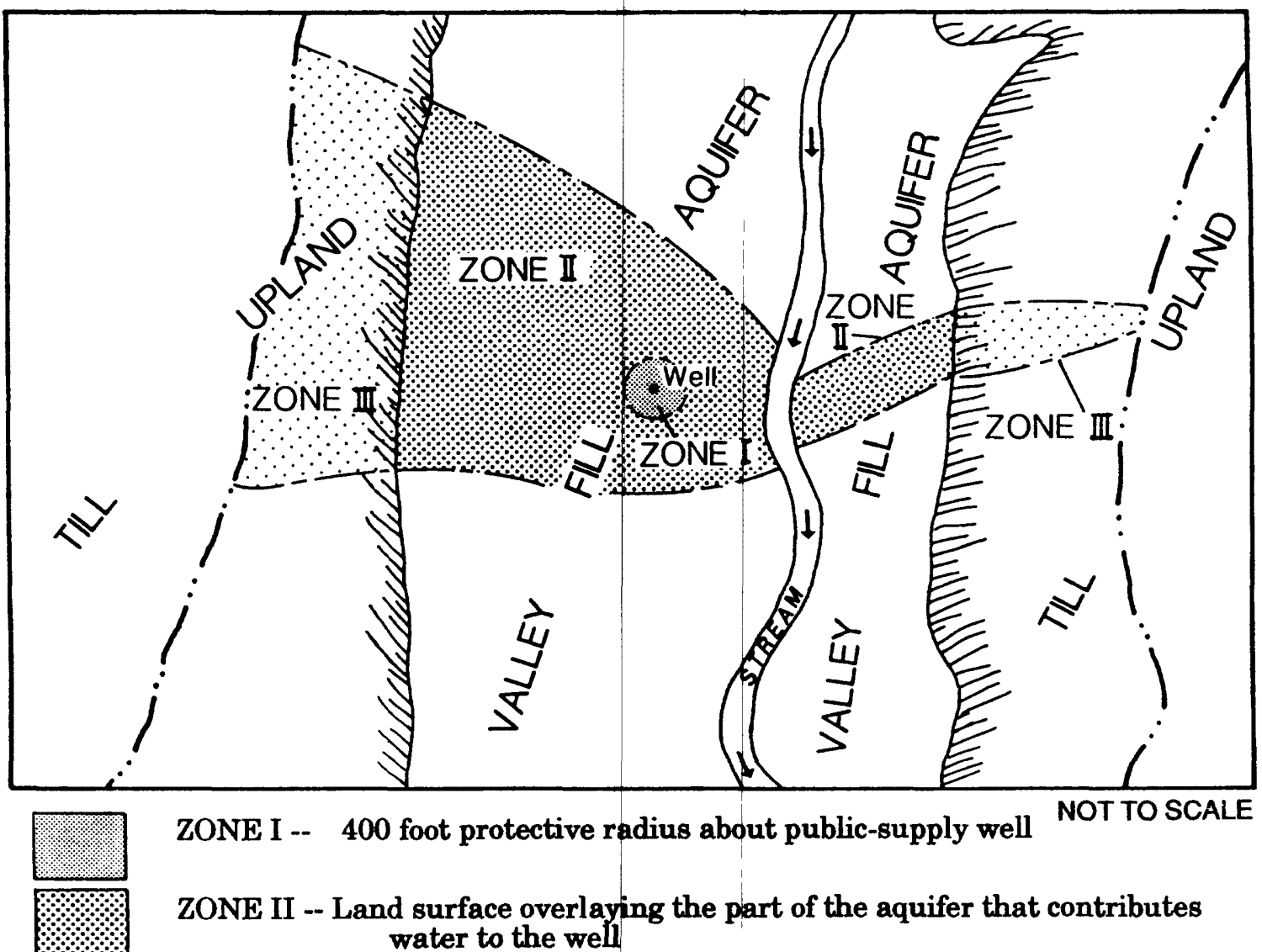

ZONE I -- 400 foot protective radius about public-supply well

NOT TO SCALE

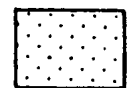

ZONE II -- Land surface overlaying the part of the aquifer that contributes water to the well

ZONE III -- Land surface through and over which water drains into Zone II

- - D DRAINAGE DIVIDE

Figure 5.--Glacial-valley aquifer showing the recharge zones and stream which contribute water to a public-supply well.

upland beyond the boundary of the aquifer from which ground and surface water drain (Zone III), the quantity and quality of such drainage need to be entered in the accounting.

3. The equations are useful for predicting concentration at the well under steady-state conditions where all of the water from the zone of contribution is mixed. Individual plumes with elevated concentrations of contaminants would be expected to emanate from septic systems and otler sources within the zone of contribution. Therefore, the prediction is not appropriate for determining contaminant concentration at other points within the aquifer, or determining the concentration in any smaller (private- domestic supply) wells within the zone of contribution.

4. After entering the saturated zone, the contaminant (nitrate) is considered to be conservative. It is not precipitated or adsorbed by aquifer materials. Attenuation in the saturated zone is assumed to occur only througl the process of dilution. Some diminisliment of nitrate through other processes is known to occur, but the quantities affected are not large enough to be considered in these gross calculations. Any clianges in water quality owing to renovation in the unsaturated zone need to be accounted for before load values are input to the mass-balance model. Reduction of source loads from the initial loads given in 
appendix $\mathbf{A}$ will be dependent on soil type, the thickness of the unsaturated zone and the interaction of the source's variable components, which are specific to each zone of contribution. No renovation is assumed in the examples given in this report because the unsaturated zone is thin (10 to $30 \mathrm{ft})$ and composed of permeable coarse sand.

5. The zone of contribution to the well is assumed to remain constant in size and shape for application of the nitrate accounting approach described here. Actually, the size of the zone is expected to become smaller as more return flow from septic systems recharges the zone of contribution, but additional recalculations of the zone of contribution would most likely be expensive and have an unacceptably high cost to benefit ratio. Therefore, this assumption results in protection of a zone slightly larger than may actually contribute water to the well and is therefore considered conservative if sources are uniformly distributed. Recharge to the aquifer is assumed to be uniform over the zone of contribution. Where variations of aquifer properties or surface-drainage characteristics cause irregular distribution of recharge, both the delineation of the zone of contribution and the calculation of contaminant concentration would have to take those variations into account. Under such conditions, the predictive approach described in this guide may not be accurate.

6. For the examples shown here, return flow of public-supply water is estimated to be 10 percent less than the quantity of water supplied because of evaporation and transpiration from outdoor uses and from septic system leach fields. Future research may indicate that the return flow from septic systems is somewhat different. The 10-percent value is based on the findings of CCPEDC and estimates for Long Island, New York. Soil conditions over other aquifers will most likely allow different rates of evaporation and transpiration with proportionate adjustment of the return flow rate.

7. On the basis of nitrate analyses of about 5,000 water samples from shallow wells on Cape Cod, the nitrate concentration of ground-water recharge was estimated to be
$0.05 \mathrm{mg} / \mathrm{L}$ for the examples in this guide. The concentration of nitrate in recharge may vary considerably from region to region primarily because of differ-ences in quality of precipitation, soils, and geology. Application of the nitrate accounting approach described here needs to take these local geochemical and hydrologic conditions into consideration.

8. By predicting nitrate loading for different pumping rates and correspondingly different zones of contribution, the effects of irregular distribution of sources may be tested. It would be possible for nitrate sources to be concentrated about a well in such a pattern that, although the nitrate planning goal is not exceeded at the maximum withdrawal rate, it might be exceeded at some lower withdrawal rate. This is a significant consideration, because withdrawal rates from an individual well are commonly changed from time to time.

\section{CONCLUSIONS}

This nitrate accounting approach can be used to predict nitrate concentrations in publicsupply wells. These predictions will allow planners and managers to recognize what level of incremental development will cause violations of nitrate planning goals thereby signaling the need to cease further development of nitrate loading activities within the zone of contribution. Alternatively, predictions may be used to indicate the level of development at which sewering within the zone of contribution would be needed to limit nitrate contamination of a public-supply well. Most importantly, this nitrate accounting approach provides a technical basis for evaluating future alternative development plans and for comparing tradeoffs between various land uses and development proposals in ground-water quality protection areas. 


\section{SELECTED REFERENCES}

Anderson - Nichols and Co., Inc., 1985, Edgartown water resource protection program final report.

Bear, Jacob, 1979, Hydraulics of groundwater: New York, New York, McGraw-Hill, Inc., 569 p.

Bennett, E.R., Leach, L.E., Enfield, C.G. and Walters, D.M., 1985, Optimization of nitrogen removal by rapid infiltration: U.S. Environmental Protection Agency, EPA/600/S2-85/016.

Cape Cod Planning and Economic Development Commission (CCPEDC), 1978, Environmental impact statement and 208 water quality management plan for Cape Cod: v. 1 and v. 2, $340 \mathrm{p}$.

1979, Water supply protection project - final report: Barnstable, Bourne, Brewster, Dennis, Yarmouth: $20 \mathrm{p}$.

Cornell University, 1974, Nitrogen utilization by crops: Cornell Field Crops Handbook.

Dewalle, F.B., Kalman, D.A., Norman, G., Plews, G., 1985, Determination of toxic chemicals in effluent from household septic tanks: U.S. Environmental Protection Agency, Water Engineering Research Laboratory EPA/600/S2-85/050, 9 p.

Dickey, E.C. and Vanderholm, D.E., 1981, Vegetative filter treatment of livestock feedlot runoff: J. Environ. Quality., v. 10, no. 3.

Donohue, J. J. IV, 1986, Zone II determination: A case study of two hydrogeological investigations: Proceedings of the Third Annual Eastern Regional Ground Water Conference, National Water Well Association, Dublin, Ohio, p. 54-63.

Dorsch, M.M., 1984, Congenital malformations and maternal drinking water supply in Rural, South Australia: American Journal of Epidemiology, John Hopkins University of Hygiene and Public Health, v. 119, no. 4, p. $473-486$.
Douglas, D.F. 1986, Literature review of the cumulative impact of on-site sewage disposal systems on nitrate - nitrogen concentrations in ground water: Ground Water Management Section, Department of Water Resources and Environmental Engineering, State of Vermont.

Eckenfelder, W.W. Jr., 1970, Water quality engineering for practicing engineers: Boston, MA, Cahner Books International, Inc.

Edwards, W.M., Chister, F.W. and Harrold, L.L., 1971, Management of barnlot runoff to improve downstream water quality: International Symposium on Livestock Wastes $\mathbf{p}$. 48-50.

Gerhart, J.M., 1986, Ground-water recharge and its effects on nitrate concentrations beneath a manured field site in Pennsylvania: Groundwater, July-August, v. 24, no. 4.

Harper, J., 1983, Turf and garden fertilizer handbook: Washington, D.C., The Fertilizer Institute.

Hem, J.D., 1970, Study and interpretation of chemical characteristics of natural water, U.S. Geological Survey Water-Supply Paper 2218.

Hinisk, W.W., 1978, Forty questions and answers on manure: Pennsylvania State University, College of Agriculture, Leaflet No. 213.

Holyoke, V., 1981, Manure is not an evil: New England Farmer, October 1979.

LeBlanc, D.R., 1984, Sewage plume in a sand and gravel aquifer, Cape Cod, Massachusetts: U.S. Geological Survey Water Supply Paper 2218, 28 p.

LeBlanc, D.R., Guswa, J.H., Frimpter, M.H. and Londquist, C.J., 1987, Ground-water resources of Cape Cod, Massachusetts: U.S. Geological Survey Hydrologic Atlas 692, 4 pls., scale 1:48,000.

Litchfield, J.H., Meat, fish, and poultry processing wastes: Water Pollution Control Federation, v. 56, no. 6.

Livestock Wastes Subcommittee, 1985, Livestock waste facilities handbook: Ames, Iowa, Midwest Plan Service, MWPS-18. 
Massachusetts Department of Environmental Quality Engineering, Division of Water Supply, 1983, Massachusetts aquifer land acquisition program regulations (310 CMR 25.00): Boston, Massachusetts, 4 p.

1986, Hydrogeologic study requirements for the delineation of Zone II and Zone III for new source approvals: Boston, Massachusetts, $11 \mathrm{p}$.

Metcalf \& Eddy, Inc. 1972, Wastewater: collection, treatment, disposal: New York, McGraw Hill.

Morrissey, Daniel J., 1987, Estimation of the recharge area contributing water to a pumped well in a glacial-drift, river-valley aquifer: U.S. Geological Survey, Open-File Report 86-543, 60 p.

Nassau-Suffolk Regional Planning Board, 1978, The Long Island comprehensive waste treatment management plan, Hauppauge, N.Y., 241 p.

National Research Council, 1977, Drinking water and health: Washington, D.C., National Academy of Sciences, 939 p.

North Carolina State University, 1978, Best management practices for agricultural nonpoint source control: Biological and agricultural engineering department, North Carolina State University, Raleigh, North Carolina.

Tchobanoglous, G., rev., 1979, Wastewater engineering: treatment disposal, reuse: New York, McGraw-Hill.

Tchobanoglous, G., Theisen, H., and Eliasses, R., 1977, Solid wastes: engineering principles and management issues: New York, McGraw-Hill Book Company.

U. S. Environmental Protection Agency, 1975, Water programs, national interim primary drinking water regulations: U.S. Environmental Protection Agency, Washington, D.C., v. 40, no. 248, Wednesday, December 24, 1975, Part IV, p. 59566-59587.

U.S. Environmental Protection Agency, October 1975, Process design manual for nitrogen control: U.S. Environmental Protection Agency, Office of Technology Transfer, Washington, D.C.
U.S. Environmental Protection Agency, 1977, Alternatives for small wastewater treatment systems, EPA/625/4-77-011.

U.S. Environmental Protection Agency, 1977, Process design manual for land treatment of municipal wastewater: U.S. Environmental Protection Agency, Office of Water Program Operations, EPA 625/-77-008 (COE EM1110-1-501).

U.S. Environmental Protection Agency, 1984, Handbook for septage treatment and disposal: U.S. Environmental Protection Agency, Environmental Research Laboratory, Ohio, EPA 625/6-84-009.

U.S. Environmental Protection Agency, U.S. Army Corps of Engineers, U.S. Department of Interior, U.S. Department of Agriculture, 1981, Process design manual for land treatment of municipal wastewater: U.S. Environmental Protection Agency, Center for Environmental Research Information, EPA/625/1-81-013 (COE EM1110-1-501).

U.S. Department of Agriculture, U.S. Environmental Protection Agency, 1979, Animal waste utilization on cropland and pastureland: USDA Utilization research report no. 6, EPA - 600-2-79-069.

Wehrmann, A.E., 1983, Potential nitrate contamination of groundwater in the Roscoe area, Winnebage County, Illinois: Champaign, Illinois, Illinois State Water Survey.

Young, R.A., Huntrods, T. and Anderson, W., 1980, Effectiveness of vegetated buffer strips in controlling pollution from feedlot runoff: Journal of Environmental Quality, v. 9 , no. 3. 


\section{APPENDIX A}

Nitrogen concentrations associated with different land uses 


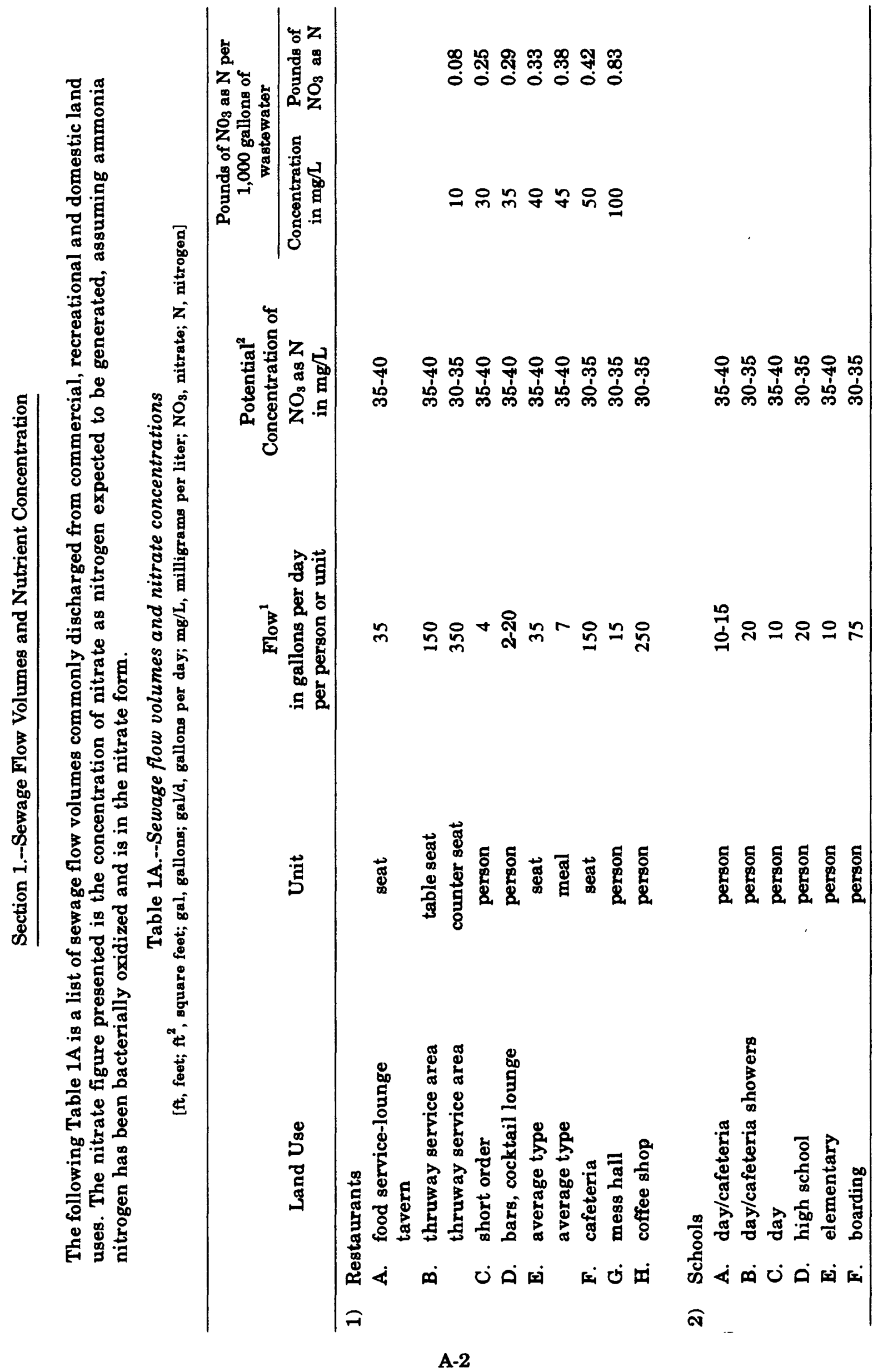




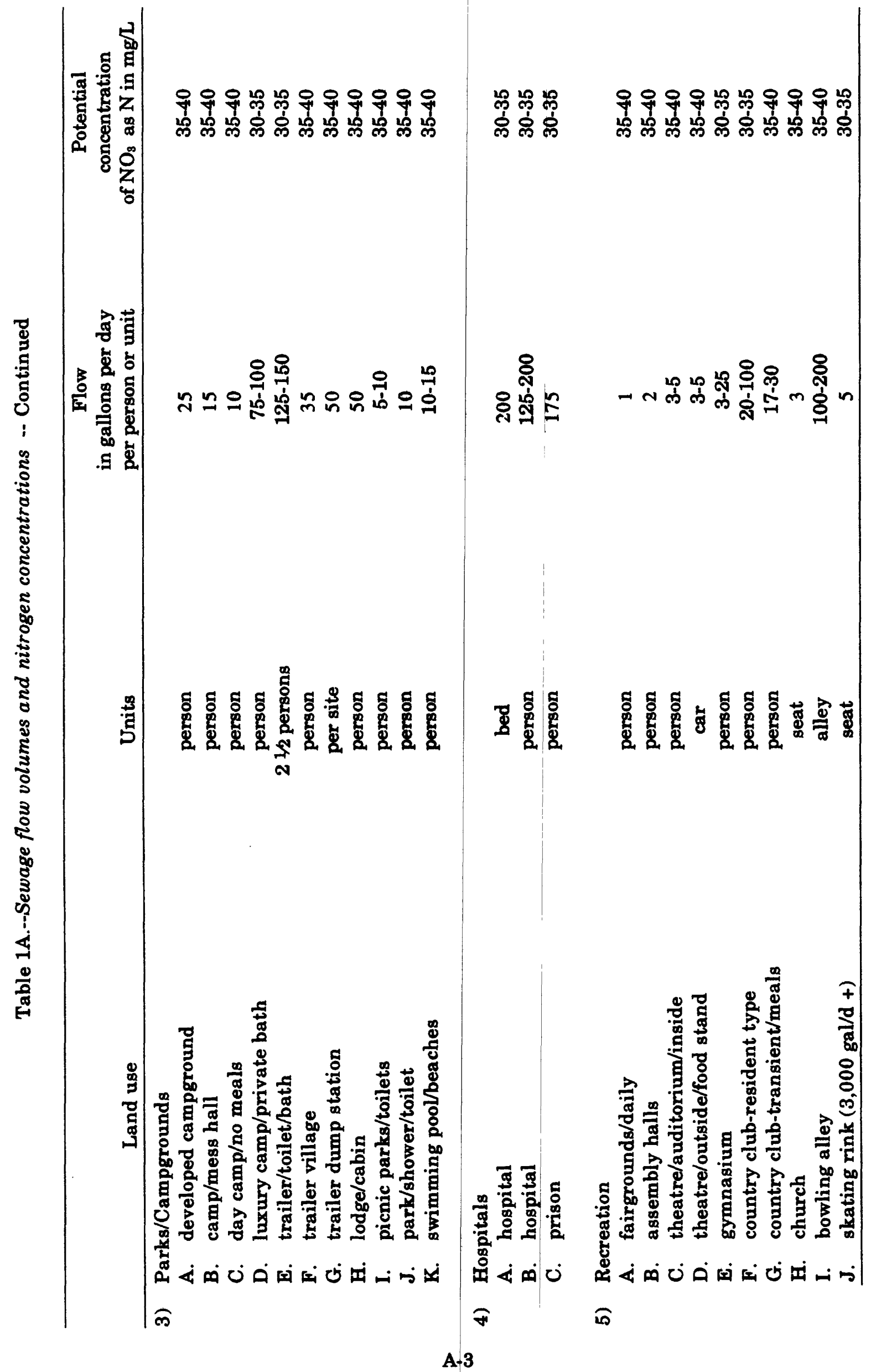




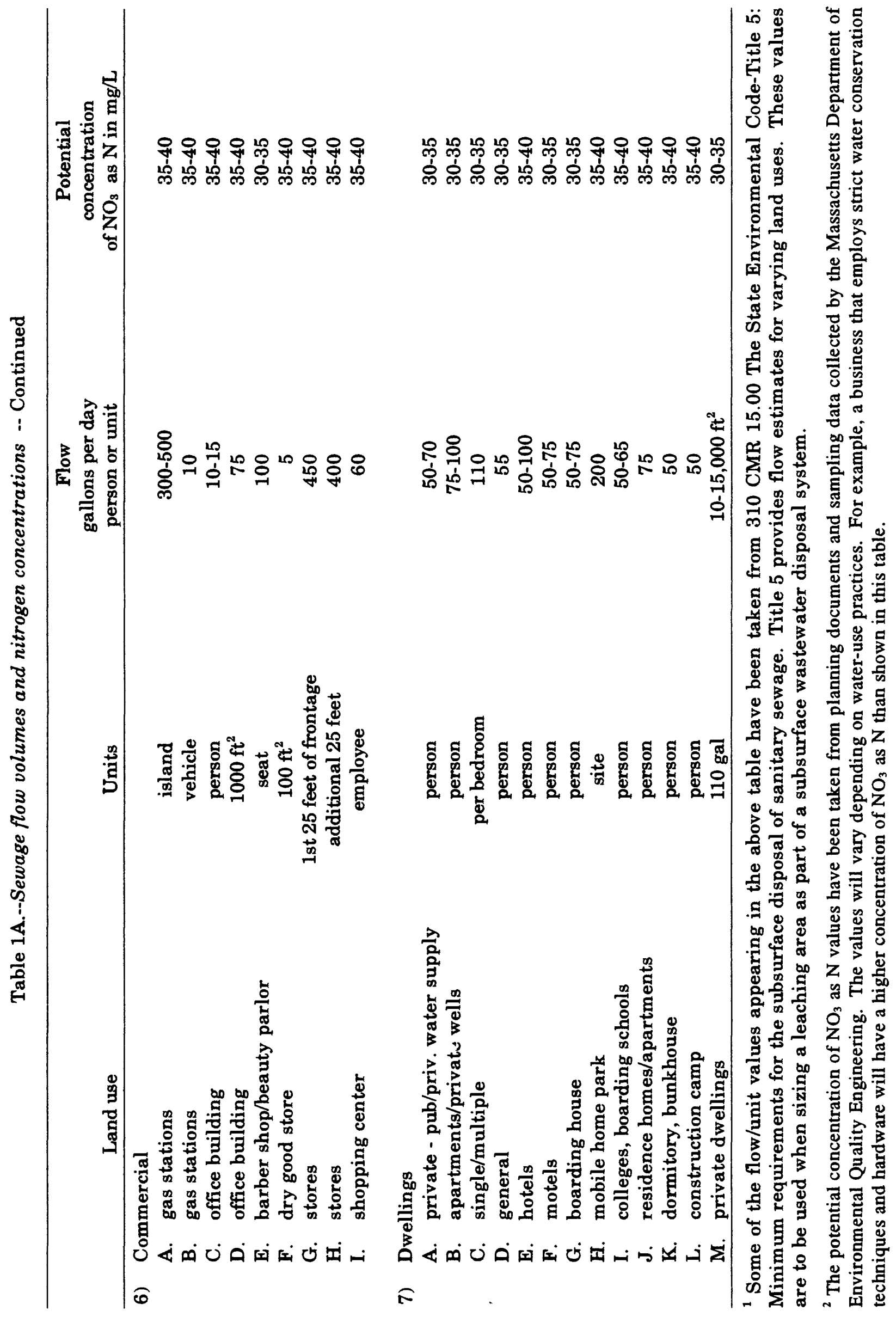




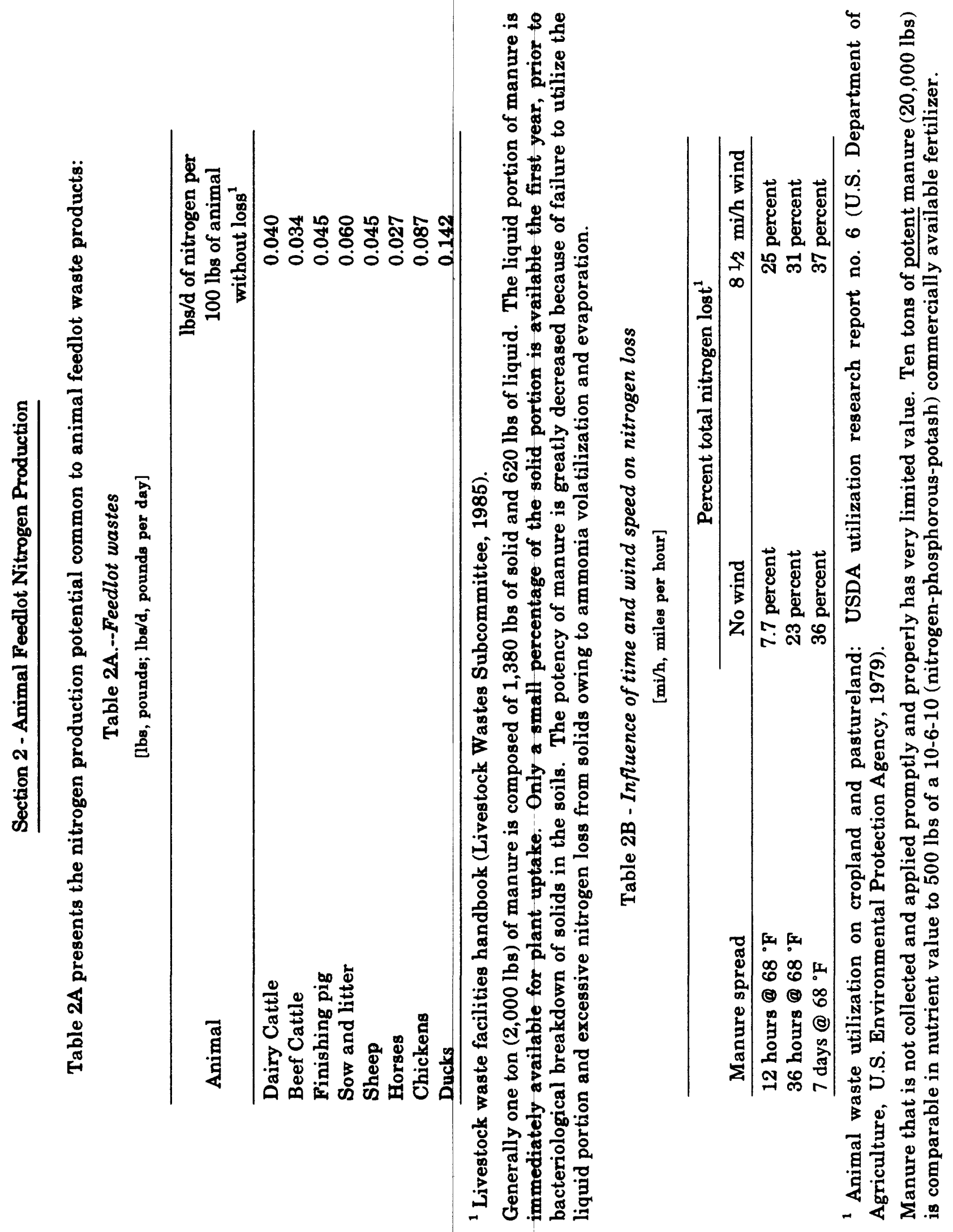




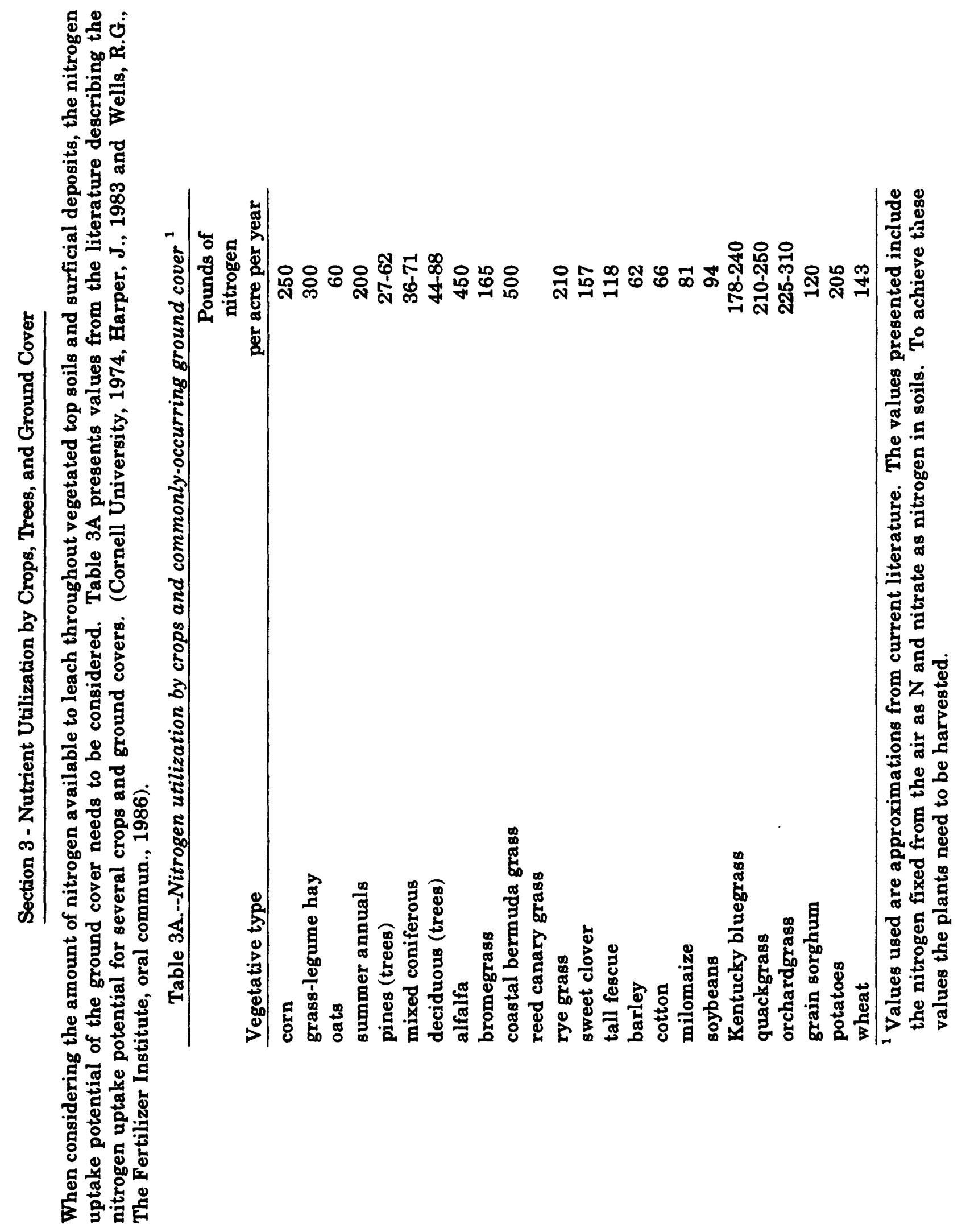




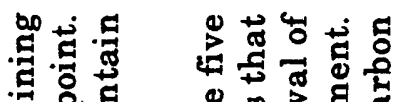

吕 吾弯实是

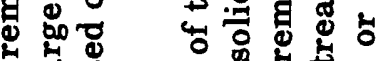

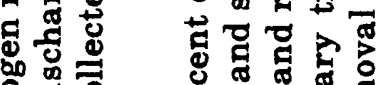

: :

乙

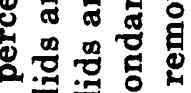

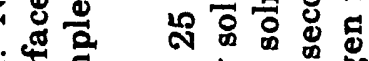

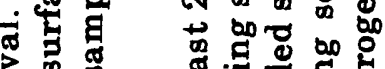

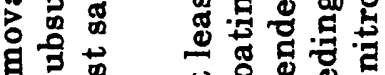

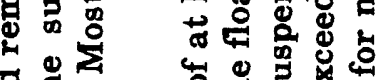

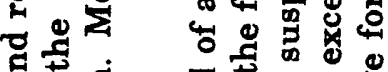

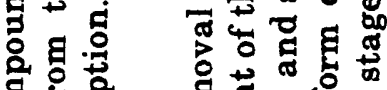

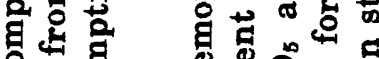

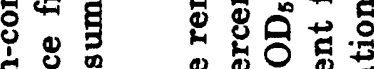

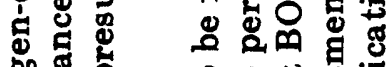

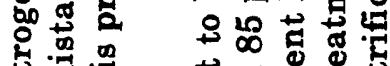

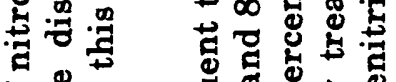

品嵒

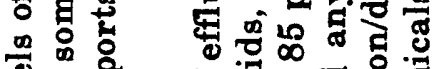

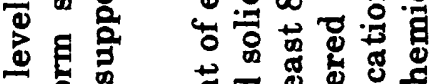

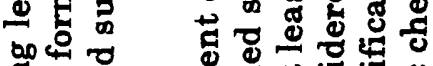

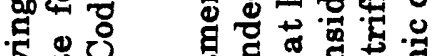

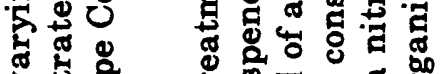

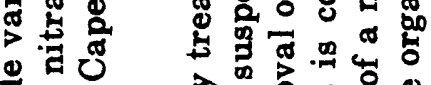

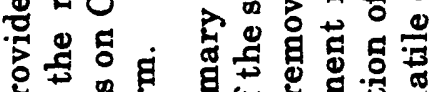

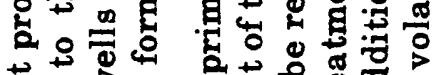

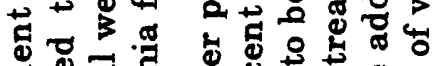

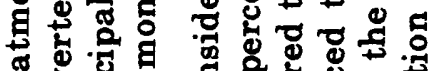

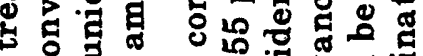

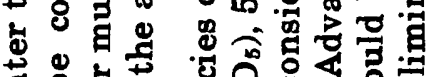

ส้ :

궁형

응

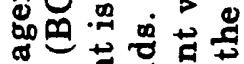

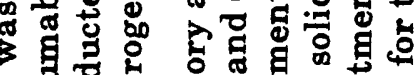

蛋壱

สํํㅇ

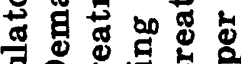

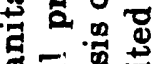

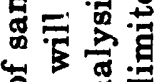

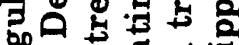

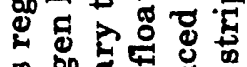

幽要

क

舟

论

己

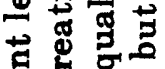

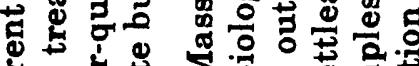

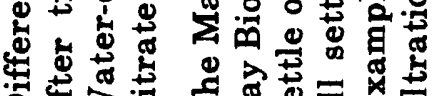

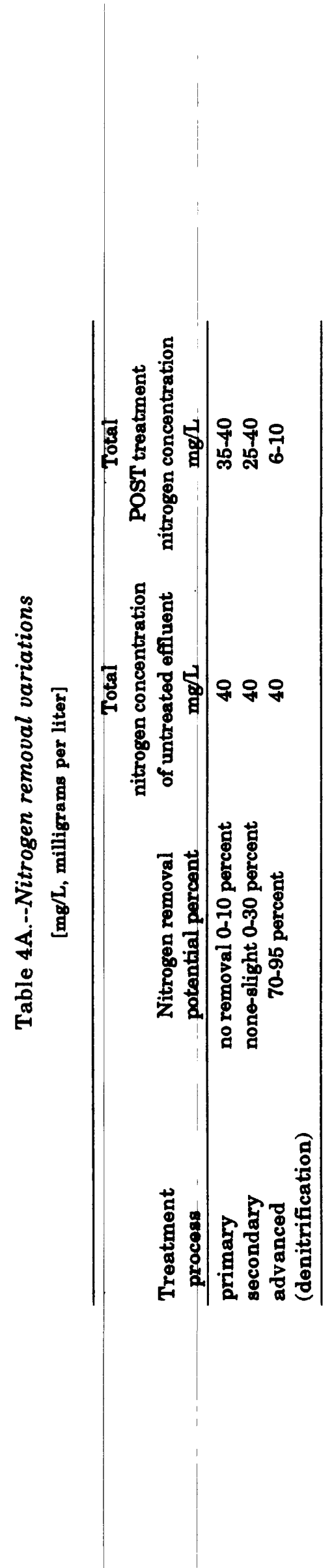

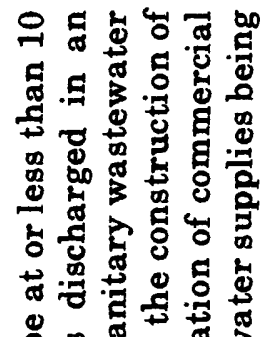

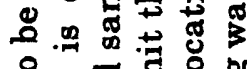

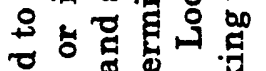

.

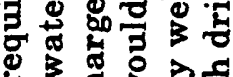

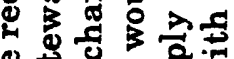

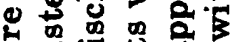

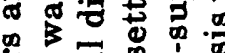

总雨总总

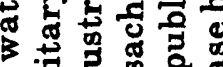

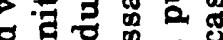

马.

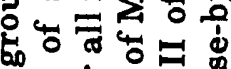

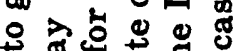

要范范

的

ส

品苾苋

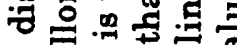

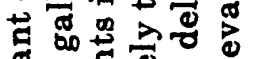

웅

응

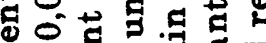

는 고연

क

$\$$ 品范

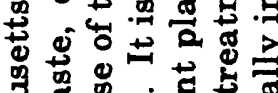

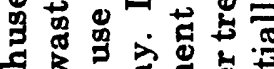

ร 3 ब

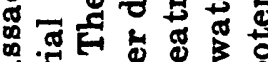

ब

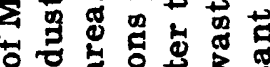

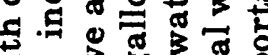

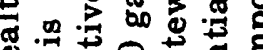

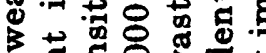

医

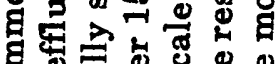

ปั

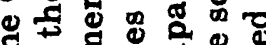

요용

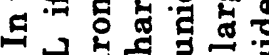

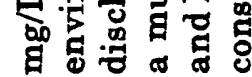



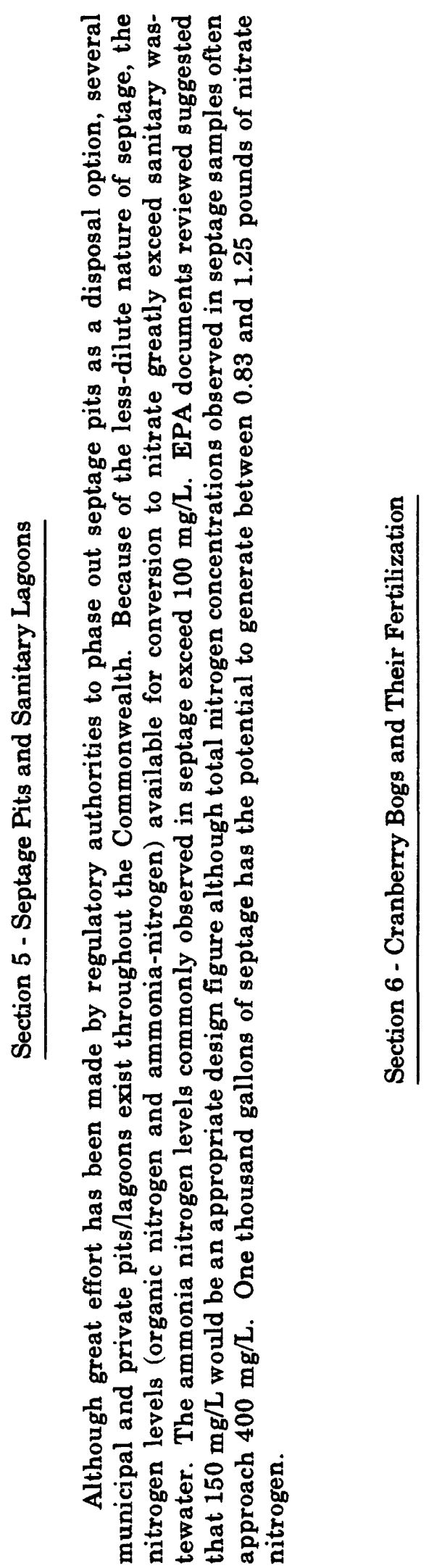

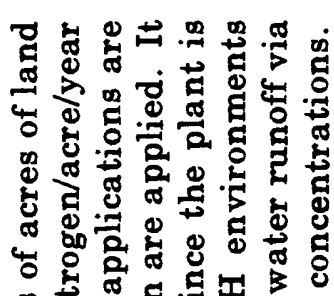

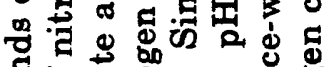

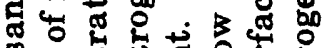

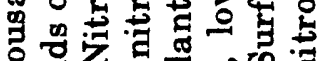

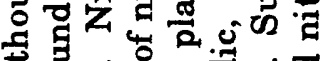

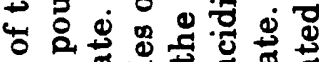

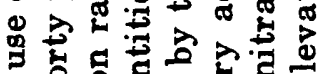

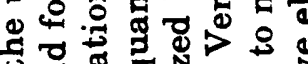

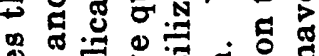

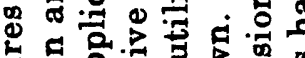

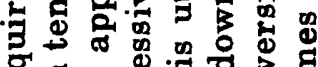

F

4 \&

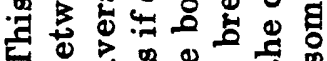

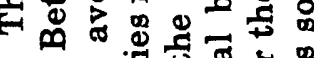

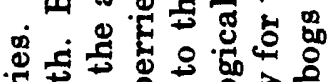

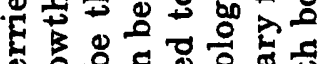

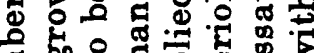

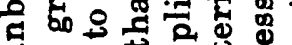

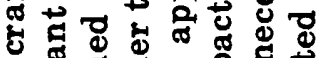

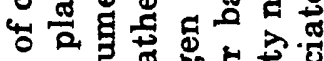

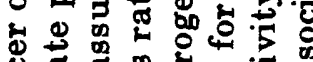

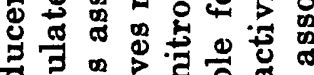

요요

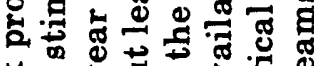

$\Rightarrow$ 年

峦 范

o :

車的

近

क्ष

究索

两

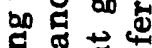

苟贾峦

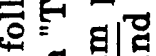

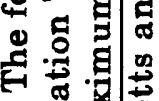

궁

范总

步 丞

政

a. 5 के

द

$\rightarrow$ क क

要济

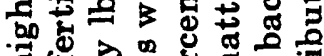

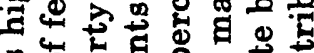

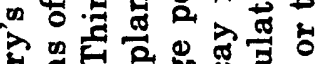

5

ठั

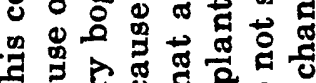

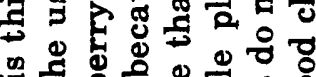

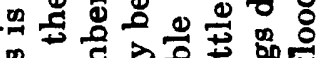

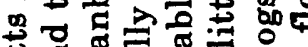

屯 ส

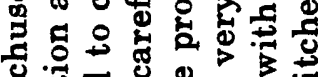

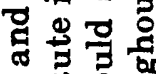

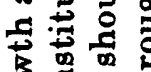

总的

5

$\stackrel{\oplus}{*}$

उ

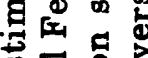

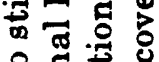

+ 둥

密范

乙运。

영 동

ลे

边壱

兽出

帘.

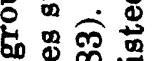

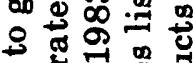

영 홍

क्ष

品 $D$.

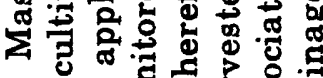

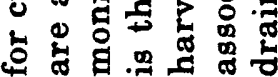

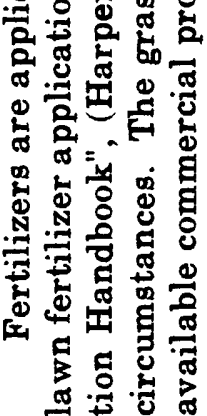




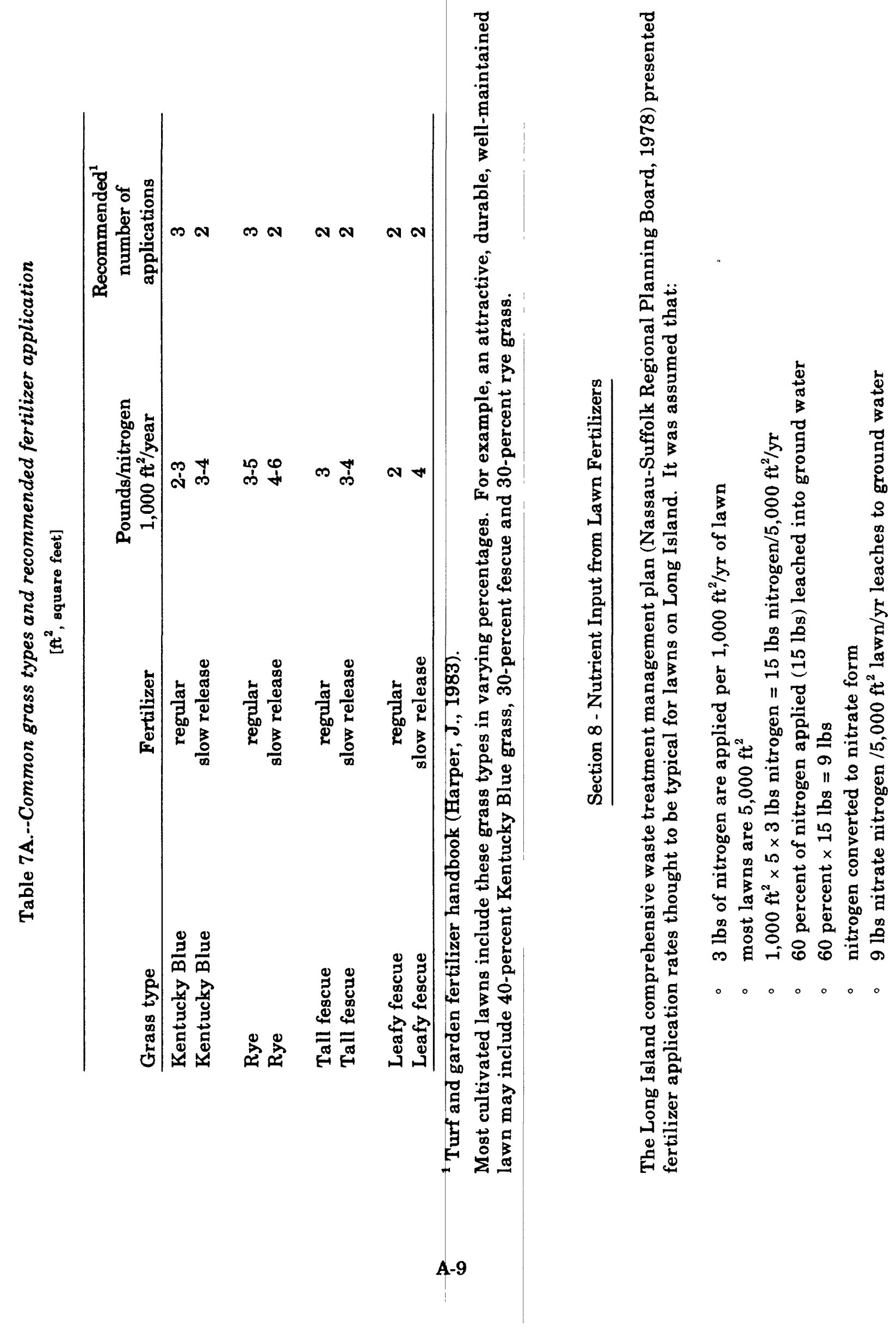



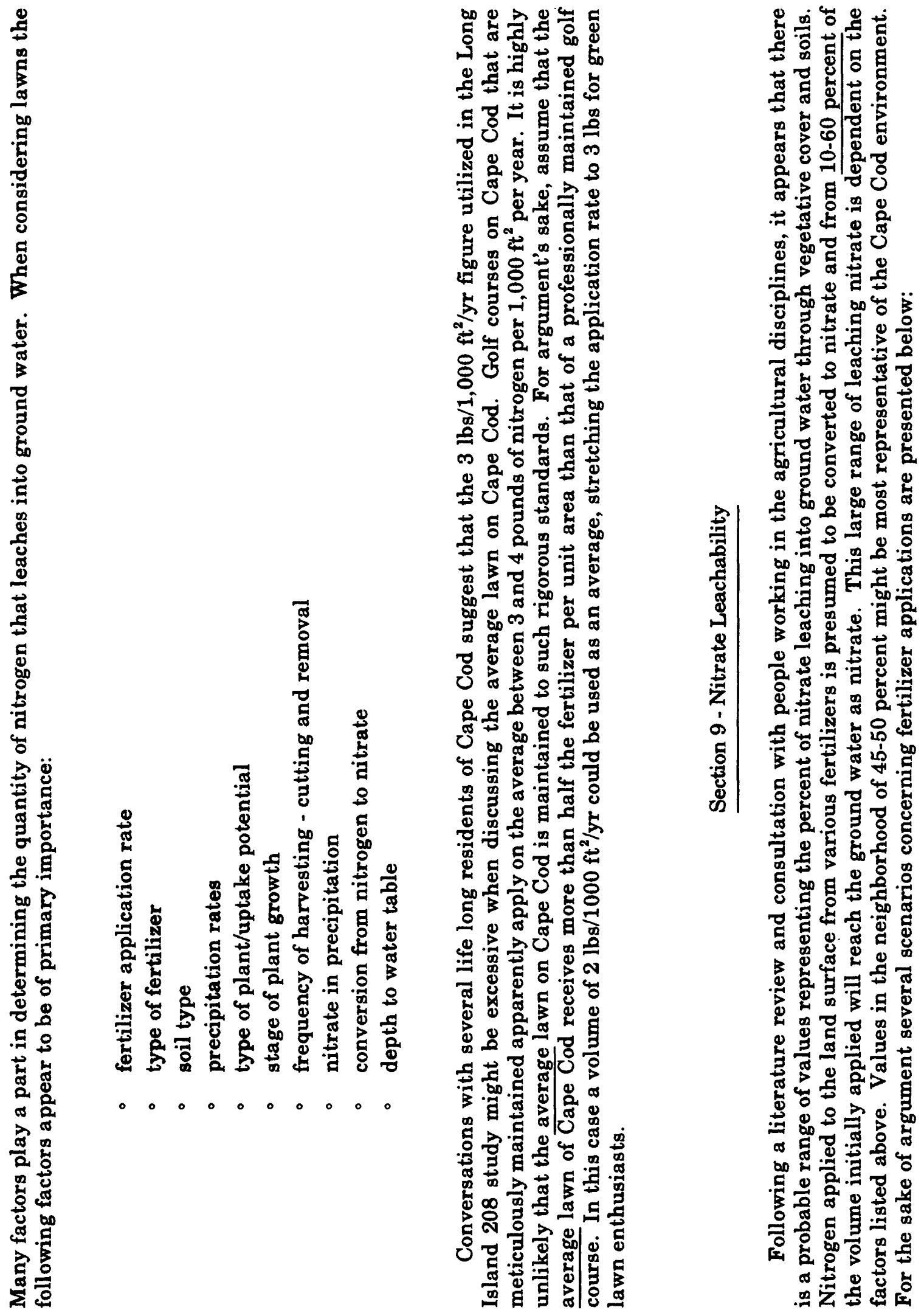


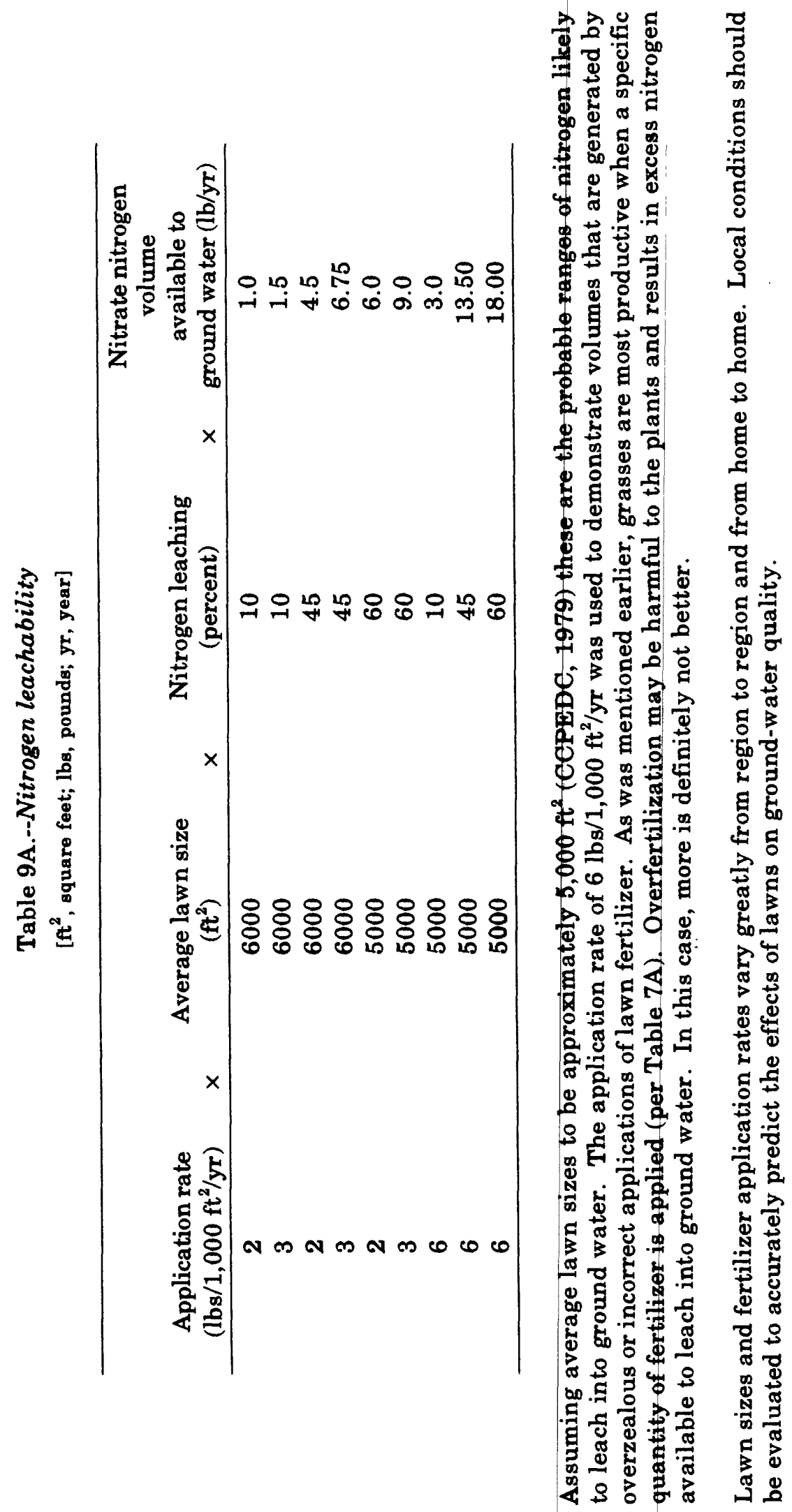




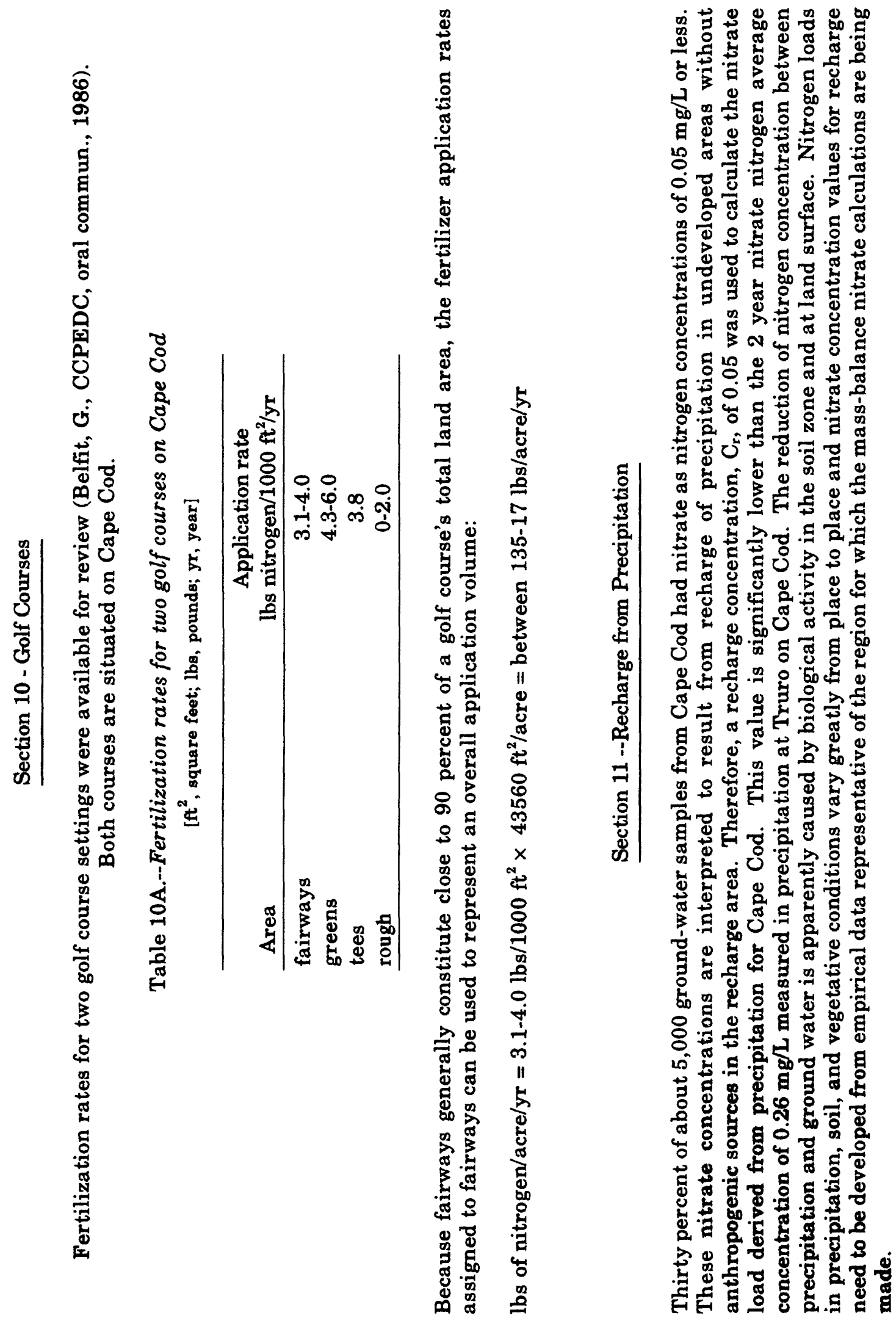




\begin{abstract}
APPENDIX B
Directions for the preparation of a computerized spreadsheet for automated calculation of nitrogen loads

by H. Gile Beye, Division of Water Supply,

Massachusetts Department of Environmental Quality Engineering
\end{abstract}


A spreadsheet to calculate nitrogen loads can easily be set up with Lotus ${ }^{1} 1-2-3$ or similar software packages. A working knowledge of the software package is prerequisite to use of the spreadsheet. The example, shown on p. B-3 and described below, uses Lotus 1-2-3. The spreadsheet is set up in seven parts. Each part generates values ultimately used in solving the nitrate-loading mass-balance equation.

The first part of the spreadsheet, summary of liquid-nitrate loads, contains data necessary to calculate the sum of liquid-nitrate load from different land uses and also to calculate the total volume of water contributed by the sources (V1 $+\mathrm{V} 2+\ldots+\mathrm{Vn})$. The spreadsheet software package does not accommodate subscripts, so the terms in the formula are modified from those presented in the text. The calculations are based on long-term averages for an arbitrary period of 1 day. The first column in part 1 of the spreadsheet is labeled SOURCE. Listed in this column is the land-use source of nitrate. The next column is labeled FLOW. The flow is the discharge from the source in gallons per day per person, seat, employee, or other unit. The next column is labeled UNITS; it lists the number of units in each land use category. The names of the units can be included to clarify the FLOW and UNITS columns, as shown in the example. To do this, set up a separate column for the names (Lotus does not allow letters to be listed in the same column as numbers that will be used for calculations). The next column is labeled VOLUME; the volume is calculated by multiplying FLOW, UNITS and a conversion factor of 3.7853 (liters per gallon). To set up this equation, type an opening (left) parenthesis, the cell address of the first value in the FLOW column, an asterisk (*), the cell address of the first value in the UNITS column, another asterisk, 3.7853, and the closing (right) parenthesis. The resultant value appears in the first cell of the VOLUME column. It represents the volume of discharge per land use in liters per day. Copy the formula into the other cells in the VOLUME column (use the copy procedure in the Lotus menu). If data are missing from the FLOW and UNITS columns, a zero will appear in the
VOLUME column. This will be automatically replaced by a value when the data are entered in those columns. The next column is labeled CONCENTRATION. It is the concentration of nitrate for each land use listed. The final column is labeled LOAD. It is the total nitrate load per land use per day. This is the product of the VOLUME and the CONCENTRATION columns. To compute the load, type an opening (left) parenthesis, the cell address of the first value in the VOLUME column, an asterisk, the cell address of the first value in the CONCENTRATION column, and then a closing (right) parenthesis. Copy this formula into each cell of the LOAD column. Then, total the VOLUME column by typing at the bottom "@SUM (cell address of first value in column ... cell address of last value in column)". Type only the information within the quotation marks, for example @SUM (G9 . . G22). This will give the value for $(\mathrm{V} 1+\mathrm{V} 2+\mathrm{Vn})$ in the final nitrate loading mass-balance equation. To total the LOAD column, follow the same procedure.

The second part of the spreadsheet, summary of solid nitrate loads, solves an equation which computes the load of solid nitrate in milligrams per day. The procedure for setting up this equation is the same as that used for the liquid nitrate equation, except there will not be a FLOW column. When the LOAD values have been calculated, total the column using the @SUM procedure. The total solid nitrate load is added to the total liquid nitrate load for a total load $(\mathrm{L} 1+\mathrm{L} 2+\ldots+\mathrm{Ln})$. Set this up as an equation on a separate line in the spreadsheet. The equation is "(cell address of total liquid nitrate load + cell address of total solid nitrate load)".

The third part of the spreadsheet is the nitrate concentration in recharge from precipitation (Cr). This varies from case to case. Enter the value to be used for the current case.

The fourth part of the spreadsheet converts the volume of pumpage from well $(\mathrm{Vw})$ from English (inch, pound) to Metric units (meter, gram). Set up the equation with gallons per day in one column and the conversion factor (3.7853) to change gallons to liters in the next column. In the third column, type "(cell address of the gal-

\footnotetext{
${ }^{1}$ Use of product or trade names is for identification purposes only and does not constitute endorsement by the authors, the U.S. Geological Survey, the Massachusetts Department of Environmental Quality Engineering, the Cape Cod Planning and Economic Development Commission, or the U.S. Environmental Protection Agency.
} 
lons per day value * cell address of the conversion factor)". The resultant value, pumpage in liters per day, will appear in the cell.

Part five of the spreadsheet, nitrate load of induced infiltration from streams, is the product of the volume of induced infiltration from streams (Vs) and the nitrate concentration of the induced infiltration (Cs).

Part six of the spreadsheet, nitrate load of drainage from Zone III to Zone II, is the product of the volume of drainage from Zone III to Zone II (VIII) and the nitrate concentration of the drainage (CIII).

Part seven of the spreadsheet, concentration at well, is the final equation. The equation using the variables defined in this spreadsheet looks like this:

$\mathrm{Cw}=[\mathrm{Cr} *[\mathrm{Vw}-\mathrm{Vs}-\mathrm{VIII}-(0.9 *(\mathrm{~V} 1+\mathrm{V} 2$

$+\ldots \mathrm{Vn}))]+[(\mathrm{L} 1+\mathrm{L} 2+\ldots \mathrm{Ln})+(\mathrm{Vs} * \mathrm{Cs})+(\mathrm{VIII} *$ CIII)] / Vw.

Set this up by typing an opening (left) parenthesis, the cell addresses of the values that correspond to the variables in the equation, and a closing (right) parenthesis. In Lotus syntax it looks like this: "C39*(F46 - (0.9*I22)) + (I35 $+\mathrm{C} 53+\mathrm{C60}) / \mathrm{F} 46$." The result is the concentration of nitrate in $\mathrm{mg} / \mathrm{L}$ at the well.

The advantage in using a spreadsheet to solve this equation is that the effects of additional or different land uses can be easily evaluated. If additions are anticipated at the time of spreadsheet generation, set up extra rows for them. When changes are made, test to be sure that accuracy in the solution of the equations is preserved.

The software package Lotus 1-2-3 was used for this example. However, a similar spreadsheet can be designed with any software package that has the capability to perform mathematical functions. This appendix describes a general format for structuring data to solve equations by means of a spreadsheet. The format can be modified to meet the requirements of other spreadsheet software. 


\section{Summary of Water Volumes and Nitrate Loads Calculated Per Day}

in the Zone of Contribution

1) Summary of liquid nitrate loado (mg/day)

\begin{tabular}{|c|c|c|c|c|c|}
\hline $\begin{array}{l}\text { SOURCE } \\
\text { (Land use) }\end{array}$ & $\begin{array}{c}\text { FLOW } \\
\text { (gallons/day) }\end{array}$ & $\begin{array}{l}\text { UNITS } \\
\text { (varies) }\end{array}$ & $\begin{array}{l}\text { VOLUME } \\
\text { (liters) }\end{array}$ & $\begin{array}{c}\text { CONCENTRATION } \\
(\mathrm{mg} / \mathrm{L})\end{array}$ & $\begin{array}{l}\text { LOAD } \\
\text { (mg) }\end{array}$ \\
\hline 1/2 acre housing & 65.00/people & 400 people & 98417.80 & 40.00 & 3936712.00 \\
\hline High school & 20.00/people & 1000 people & 75706.00 & 40.00 & 3028240.00 \\
\hline Fast food table seats & $150.00 /$ seat & 70 seats & 39745.65 & 40.00 & 1589826.00 \\
\hline Fast food counter seats & 350.00/seat & 10 seats & 13248.55 & 35.00 & 463699.25 \\
\hline 1 acre housing & $65.00 /$ people & 200 people & 49208.90 & 40.00 & 1968356.00 \\
\hline Condominiums & 65.00/people & 120 people & 29525.34 & 40.00 & 1181013.60 \\
\hline Shopping center & 60.00/employee & 50 employees & 11355.90 & 40.00 & 454236.00 \\
\hline Office building & 15.00/employee & 25 employees & 1419.49 & 40.00 & 56779.50 \\
\hline Gas station & 500.00/island & 2 islands & 3785.30 & 40.00 & 151412.00 \\
\hline Church & $3.00 /$ seat & 200 seats & 2271.18 & 40.00 & 90847.20 \\
\hline Motel & 75.00/people & 40 people & 11355.90 & 35.00 & 397456.50 \\
\hline Motel & 75.00/people & 160 people & 45423.60 & 35.00 & 1589626.00 \\
\hline Hospital & 200.00/bed & 60 beds & 45423.60 & 35.00 & 1589826.00 \\
\hline
\end{tabular}

2) Summary of solid nitrate loads (mg/day)

SOURCE

100 lawns@ @ $5000 \mathrm{ft}^{2}$ each

6 horses@ 1200 lbs. each

$$
\begin{aligned}
& \text { UNITS } \\
& \text { (varies) }
\end{aligned}
$$

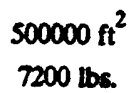

\section{NITRATE}

(lbs)

\section{CONVERSION}

(me/n)

451000

451000

of animal

LOAD

(me)

113500000

882576.00

\section{Total solid LOAD $=\quad 2017576.00$}

3) (Cr) - Nitrate concentration in recharge from precipitation.

$$
0.05 \mathrm{mg} / \mathrm{L}
$$

4) $(V w)$ - Volume of pumpage from well

$\begin{array}{ccc}\begin{array}{c}\text { VOLUME } \\ \text { (GPD) }\end{array} & \begin{array}{c}\text { CONVERSION } \\ \text { (GPD) } \times 3.7853\end{array} & \text { L/day } \\ 1000000 & 3.7853 & 3785300\end{array}$

5) Nitrate load of induced infiltration concentration from atreams

(Vs) - Volume of induced infiltration from streams

$0.00 \mathrm{~L}$

(Cs) - Nitrate concentration in induced infiltration

$0.00 \mathrm{mg} / \mathrm{L}$

$\left(\mathrm{V}_{B} * \mathrm{Cs}_{\mathrm{B}}\right)=0.00 \mathrm{mg}$

6) Nitrate load of drainage from Zone III to Zone II

(VIII) - Volume of drainage from Zone III into Zone II

$0.00 \mathrm{~L}$

(CIII) - Nitrate concentration of drainage from Zone III to Zone II

$0.00 \mathrm{mg} / \mathrm{L}$

$($ VIII * CIII $)=0.00 \mathrm{mg}$

7) $(\mathrm{Cw})$ - Concentration of nitrate at well

$\mathrm{Cw}_{\mathrm{w}}=[\mathrm{Cr} *[\mathrm{Vw}-\mathrm{Vs}-\mathrm{VIII}-(0.9 *(\mathrm{~V} 1+\mathrm{V} 2+\ldots \mathrm{Va}))]+(\mathrm{L} 1+\mathrm{L} 2+\ldots \mathrm{Ln})]+(\mathrm{Vs} \times \mathrm{Cs})+(\mathrm{VIII} \times \mathrm{CIII}) / \mathrm{V}_{\mathrm{w}}$

$\mathrm{Cw}=4.94 \mathrm{mg} / \mathrm{L}$ 


\section{APPENDIX C}

List of acronyms, chemical formulas and mathematical symbols used 
Acronyms

BOD $_{5}$ : $\quad 5$ day biological oxygen demand

CCAMP: Cape Cod Aquifer Management Project

CCPEDC: Cape Cod Planning and Economic Development Commission

CMR: $\quad$ Code of Massachusetts Regulations

GPD: $\quad$ gallons per day

\section{Mathematical Symbols}

$\mathrm{C}_{\mathrm{n}}$ : $\quad$ nitrate concentration in individual sources $(\mathrm{mg} / \mathrm{L})$

$\mathrm{C}_{\mathbf{r}}$ : nitrate nitrogen concentration in recharge from precipitation $(\mathrm{mg} / \mathrm{L})$

$\mathrm{C}_{\mathrm{s}}$ : nitrate concentration in induced infiltration $(\mathrm{mg} / \mathrm{L})$

$\mathrm{C}_{\mathrm{m}}$ : nitrate nitrogen concentration at well $(\mathrm{mg} / \mathrm{L})$

$\mathrm{C}_{\mathrm{III}}$ : nitrate concentration of drainage from Zone III to Zone II ( $\left.\mathrm{mg} / \mathrm{L}\right)$

$L_{n}$ : nitrate nitrogen load in milligrams for individual septic systems

$V_{n}$ : volume of water used by each source before discharge to septic system (liters)

$V_{\mathrm{a}}$ : volume of induced infiltration from streams (liters)

$\mathrm{V}_{\mathrm{w}}$ : volume of withdrawal from well (liters)

$\mathrm{V}_{\text {II }}$ : $\quad$ volume of drainage from Zone III into Zone II (liters)

\section{Chemical Formulas}

N: $\quad$ nitrogen

$\mathrm{N}_{2}$ : nitrogen (atmospheric)

$\mathrm{NO}_{2}: \quad$ nitrite nitrogen

$\mathrm{NO}_{3}: \quad$ nitrate nitrogen

$\mathrm{NH}_{3}$ : ammonia nitrogen

$\mathrm{NH}_{4}$ : $\quad$ ammonia nitrogen (ionized) 